Teologia i Moralność, Volumen 13(2018), numer 1(23)

doi: 10.14746/tim.2018.23.1.6

\author{
ROBERT PLICH \\ Uniwersytet Papieski Jana Pawła II w Krakowie \\ Wydział Teologiczny
}

\title{
Legalistyczna neutralizacja nauki o czynach wewnętrznie złych i absolutnych zakazach moralnych w adhortacji Amoris laetitia
}

Treść niniejszego artykułu stanowi krytykę rozwiązania dyscyplinarnego i przekonania o jego spójności z nauczaniem moralnym Kościoła przedstawionego przez papieża Franciszka w ósmym rozdziale jego adhortacji Amoris laetitia. Kontrowersyjnym rozwiązaniem dyscyplinarnym, odmiennym od dotychczasowej praktyki Kościoła, lecz promowanym przez papieża Franciszka w jego adhortacji, jest dopuszczenie do Komunii Świętej (AL) przynajmniej niektórych osób żyjących w związku utworzonym na gruncie wzajemnego pożycia seksualnego, który nie stanowi jednak małżeństwa kanonicznego. Kościół wierny nauce Chrystusa zawsze uczył, że akty seksualne w takich związkach są cudzołóstwem, a więc czynem wewnętrznie złym, objętym absolutnym zakazem moralnym, który nie dopuszcza wyjątków. Dlatego o ile z poważnych przyczyn (np. dobro dzieci zrodzonych z takiego związku) dotychczas Kościół tolerował wspólne zamieszkanie takich osób, o tyle nigdy, nawet w takiej sytuacji, nie tolerował ich wzajemnego współżycia seksualnego (por. FC, nr 84; KKK, nr 1650; Kongregacja Nauki Wiary 1994; Papieska Rada ds. Interpretacji Tekstów Prawnych 2000). Tymczasem wydaje się, że papież Franciszek, nie zmieniając formalnie dotychczasowej doktryny ani nie zamierzając formułować norm typu kanonicznego (por. AL, nr 300), w efekcie doprowadza do tolerowania $\mathrm{w}$ pewnych przypadkach takiego współżycia, postrzeganego dotychczas jako cudzołóstwo, i do umożliwienia praktykującym je osobom przystępowania do Komunii Świętej. Potwierdza to także interpretacja ad- 
hortacji Amoris laetitia dokonana przez biskupów regionu Buenos Aires, którą następnie papież oficjalnie autoryzował ${ }^{1}$.

Autor adhortacji Amoris laetitia nie artykułuje explicite żadnych zmian doktrynalnych, stąd - jak wolno przypuszczać - nie zamierza uczyć nowych prawd wiary i moralności ponad te, które zostały już wyrażone w nauczaniu Kościoła. Można odnieść wrażenie, że papieski dokument bardziej służy promocji pewnej praktyki duszpasterskiej i przygotowaniu dla niej gruntu w kościelnej dyscyplinie przy założeniu, że pozwala na to dotychczasowa doktryna, której wcale nie trzeba zmieniać. Nie odwołując zatem zastanej doktryny, tekst papieskiego dokumentu daje podstawy ku pewnej jej reinterpretacji, aby w ten sposób przystosowana nie generowała trudności we wprowadzeniu promowanego rozwiązania duszpastersko-dyscyplinarnego. Jednym ze sposobów tej reinterpretacji i adaptacji doktryny może być dyskretnie przeprowadzona relatywizacja tradycyjnej nauki Kościoła, wywodzącej się z Pisma Świętego, dotyczącej czynów wewnętrznie złych i zabraniających ich popełniania absolutnych zakazów moralnych. Ponieważ nikt w sposób odpowiedzialny nie jest w stanie ostentacyjnie odrzucić tej nauki, głoszonej ze stałością przez Kościół w ciągu wieków, dlatego można odnieść wrażenie, że tekst adhortacji stanowi pewną próbę neutralizacji czy obejścia tych zasad poprzez akcentowanie roli innych elementów obecnych w doktrynie i teologicznej tradycji moralnej.

Jeśli wspomniana adaptacja doktryny okazałaby się zamierzona przez papieża, to pojawia się pytanie, czy aby papież zbyt optymistycznie nie ocenia chłonności dotychczasowej doktryny i jej możliwości adaptacyjnych w bezkonfliktowym przyjmowaniu przez nią propagowanego w adhortacji duszpasterskiego i dyscyplinarnego rozwiązania. Doktryna Kościoła może być porównana do prawidłowo działającego sytemu immunologicznego organizmu. System ten broni cały organizm przed tym, co jest dla niego antygenowo obce, a próby osłabienia tej obrony mogą skończyć się tragicznie dla wszystkich jego członków. Podobnie jest z doktryną, której neutralizacja i osłabianie w dziedzinie moralności może skończyć się relatywizmem i chaosem ze szkodą dla dobra człowieka, które jest przecież celem moralności.

Dlatego w niniejszym artykule postaramy się uwidocznić kilka charakterystycznych rozwiązań zastosowanych w adhortacji Amoris laetitia, które mogły się tam znaleźć w celu zrelatywizowania nauki o czynach wewnętrznie złych i absolutnych zakazach moralnych. Wskażemy jednocześnie na po-

${ }^{1}$ Interpretacja ta oraz jej papieska aprobata ukazały się 5-IX-2016, a następnie zostały opublikowane jako: Epistula apostolica ad Excellentissimum Dominum Sergium Alfredum Fenoy, delegatum Regionis Pastoralis Bonaërensis, necnon adiunctum documentum (de praecipuis rationibus usui capitis VIII Adhortationis post-synodalis “Amoris Laetitia”), „Acta Apostolicae Sedis” 108 (2016), s. 1071-1074. 
ważne wady takich zabiegów. Dostrzeżenie ich obecności w adhortacji Amoris laetitia oraz rozpoznanie ich strategicznej roli nie jest łatwe $\mathrm{z}$ powodu użycia w tym papieskim dokumencie nieprecyzyjnego języka oraz pewnych zabiegów retorycznych. Chociaż ta niejednoznaczność i retoryka mogą stanowić swego rodzaju neutralizujący kamuflaż dla propagowanych zmian, to jednocześnie na szczęście uniemożliwiają odczytanie tych modyfikacji jako jednoznacznego stanowiska papieskiego Magisterium. Rozwiązania zawarte $\mathrm{w}$ adhortacji nie są bowiem wyrażone wprost, wyraźnie i w jasny sposób. Są one wyartykułowane w sposób niebezpośredni, domyślny, czasem wręcz niejasny, z kontrowersyjnym powoływaniem się na inne źródła pisane wbrew intencji ich autorów, możliwej przecież do odczytania z szerszego kontekstu tych źródłowych tekstów. Natomiast tezy, które mogą sprawiać wrażenie najbardziej rewolucyjnych i jednocześnie najbardziej kontrowersyjnych, zostały wyrażone domyślnie w przypisach, zamiast w wyraźny sposób w tekście głównym (por. AL - przyp. 329, 336, 351). Taki zabieg nasuwa pytanie, czy w ten sposób papież sprawuje swoje Magisterium i chce nauczać, czy raczej pragnie jedynie coś zasugerować w materii trudnej, gdzie - jak sądzi - nie ma prostych odpowiedzi (por. AL, nr 298).

Co więcej, dyscyplinarno-duszpasterski charakter, jaki wydaje się mieć rozwiązanie dopuszczone $\mathrm{w}$ adhortacji, sprawia, że ze swej natury nie musi być ono nieomylne i w związku z tym dopuszcza krytyczną refleksję i dyskusję. Nie przeczy temu nawet oficjalna papieska aprobata interpretacji tej adhortacji, dokonanej przez biskupów regionu Buenos Aires. Interpretacja ta uwidacznia jedynie, że rzeczywiście intencją papieża jest dopuszczenie osób żyjących w powtórnych związkach do sakramentów. Nie musi to wcale oznaczać jakiejś zmiany w nieomylnym nauczaniu doktrynalnym Magisterium, lecz może stanowić jedynie wyjaśnienie intencji papieskiego praktycznego rozwiązania, którego wartość papież chce koniecznie ocenić przez wdrożenie go w życie, poczynając przynajmniej od niektórych regionów Kościoła. Nie muszą być zatem przejawem niewierności Magisterium krytyczne refleksje, reakcje i dyskusje, jakie adhortacja sprowokowała w Kościele, co można było zaobserwować w ciągu minionego czasu, który upłynął od jej ogłoszenia. Także poniższy artykuł wraz $\mathrm{z}$ wyrażonym $\mathrm{w}$ nim stanowiskiem autora wpisuje się w ten sceptyczny oddźwięk wzbudzony przez adhortację.

Ponadto, chociaż posynodalna adhortacja papieska ze swej natury jest dokumentem angażującym autorytet Magisterium w poważnym stopniu, to mimo to taka forma wypowiedzi biskupa Rzymu nie stanowi jeszcze teologicznego kryterium nieomylności treści w niej zawartych. Taka charakterystyka adhortacji umożliwia sumieniu teologa wiernego nauczaniu Magisterium zajęcie krytycznego stanowiska wobec niektórych elementów treści dokumentu, zwłaszcza jeśli wydają się nie do pogodzenia z dotychczasowym nauczaniem 
Magisterium. Niemylność papieża i Kościoła dotyczy nauczania prawd wiary i moralności, a więc doktryny, a nie rozwiązań praktycznych i dyscyplinarnych, które mogą się przecież zmieniać, i to nawet radykalnie, w taki sposób, że jedno odwołuje drugie. Choć w dziedzinie doktryny jest również możliwy pewien rozwój, to jednak nie może się on prowadzić do radykalnych zmian i zerwania z poprzednim nauczaniem, gdzie jedna prawda zaprzecza innej i odwołuje ją, ponieważ jeśli jakaś treść stanowi prawdę wiary i moralności, to z natury prawdy ma ona charakter niezmienny i ponadczasowy. Określona treść nie może przecież raz być prawdą, a innym razem nią nie być, a zwłaszcza w tak istotnej dziedzinie, jaką jest zbawienie i sens życia ludzkiego.

Poza tym, nauka o nierozerwalności małżeństwa i cudzołóstwie nie tylko została przez Jezusa wzmocniona dzięki wyniesieniu małżeństwa do rangi sakramentu (por. Ef 5,31-32; KPK kan. 1055 § 1; KKK, nr 1601), ale także z istoty swej wynika z zamysłu Stwórcy, a więc z prawa naturalnego, o czym Jezus wyraźnie przypomina, odrzucając zafałszowania, jakim została ona poddana w dziejach ludzkości (por. Mt 19,1-9 oraz Mk 10,2-12 wraz z odniesieniem do Rdz 1,27; 2,24). Oznacza to, że Magisterium Kościoła nie może jej zmieniać. Kościół bowiem nie tylko nie może zmieniać nauki Jezusa, ale nie ma też władzy nad prawem naturalnym. Magisterium może najwyżej rozpoznawać prawo naturalne, deklarować je, oczyszczać i interpretować jego rozumienie, ale nie ma władzy, aby je ustanawiać, zmieniać czy odwoływać. Zresztą sam papież już na wstępie zaznaczył, że „nie wszystkie dyskusje doktrynalne, moralne czy duszpasterskie powinny być rozstrzygnięte interwencjami Magisterium" (AL, nr 3). Wydaje się więc, że cele, jakie postawił sobie papież, to przede wszystkim ukierunkowanie refleksji, dialog oraz duszpasterska pomoc rodzinom (por. AL, nr 4). Pisząc tę adhortację, papież - jak sam przyznał - zdawał sobie sprawę, że chociaż różne osoby zależnie od swego stanu mogą być zainteresowane bardziej pewnymi fragmentami adhortacji, a mniej innymi, to jednak ,wszyscy będą bardzo zaintrygowani rozdziałem ósmym” (AL, nr 7). W tym na pewno się nie pomylił.

\section{Rekonstrukcja funkcji, jaką pełnią okoliczności lagodzące według adhortacji Amoris laetitia}

Zgodnie z tradycją teologiczną i nauczaniem Kościoła, okoliczności czynu ludzkiego wraz z jego wybranym przedmiotem i zamierzonym celem, czyli intencją, stanowią tzw. „źródła moralności”, czyli elementy strukturalne czynu, od których zależy jego moralna jakość. O ile przedmiot i cel stanowią istotne wyznaczniki tej jakości, o tyle okoliczności mają dla niej charakter przypadłościowy. Oznacza to, że okoliczności mogą zwiększać bądź zmniejszać mo- 
ralną jakość czynu oraz osłabiać bądź wzmacniać odpowiedzialność moralną osoby działającej, natomiast nie zmieniają moralnej jakości samego czynu na przeciwną (czyli np. nie zmieniają złego czynu w dobry; por. KKK, nr 1750-1761; Tomasz z Akwinu 1891-1897, I-II, q. 18). W związku z tym wyróżnia się okoliczności łagodzące, pomniejszające odpowiedzialność moralną podmiotu oraz okoliczności obciążające, które odpowiedzialność tę zwiększają. Okoliczności łagodzące są przedstawione w adhortacji Amoris laetitia jako ważne dla oceny moralnej specyficzne cechy sytuacji zwanych „nieregularnymi”. Sytuacje te określane są jako nieregularne, ponieważ zostały spowodowane różnymi formami związków dwóch osób płci przeciwnej (mężczyzny i kobiety), niebędących małżeństwem kanonicznym, chociaż utworzonych na podstawie wzajemnych relacji seksualnych. Ponieważ istnieją rozmaite rodzaje takich związków, które szczegółowo wyróżnia tradycja kanoniczna (por. Nowicka, 2016, s. 443-455; Lepa 2013, s. 167-171) i które w jakiejś mierze w sposób niejednoznaczny, lecz analogiczny, realizują istotę małżeństwa, dlatego są one określone w adhortacji zbiorczo mianem ,związków w sytuacjach «nieregularnych»"2. Występujące w tych sytuacjach okoliczności łagodzące nie zamieniają wprawdzie kwalifikacji takich sytuacji z nieregularnej $\mathrm{w}$ regularną i nie zamieniają związku między tymi osobami w małżeństwo kanoniczne, to jednak - zdaniem autora adhortacji - mogą łagodzić negatywną moralną ocenę osób tworzących taki związek i ich wzajemnych aktów seksualnych, pozwalając na głębsze uczestnictwo tych osób w życiu duchowym Kościoła (por. AL, nr 300). Sięgając po koncepcję okoliczności łagodzących, papież Franciszek nie wynajduje czegoś zupełnie nowego, ale jak sam przyznaje, posługuje się „solidną refleksją na temat uwarunkowań i okoliczności łagodzących”, którą dysponuje Kościół (por. AL, nr 301). W związku z tym okoliczności łagodzące stanowią przedmiot rozeznania duszpasterskiego, którego celem jest objęcie pomocą duszpasterską osób znajdujących się we wspomnianych sytuacjach „nieregularnych”. Oprócz wspomnianych okoliczności łagodzących, zmniejszających moralną odpowiedzialność, rozeznanie duszpasterskie powinno brać także pod uwage prawidła rozwoju moralnego człowieka, a zwłaszcza prawo stopniowości w dochodzeniu do życia w pełni moralnie dobrego, o którym uczył już Jan Paweł II w adhortacji Familiaris consortio (por. FC, nr 34).

Papież Franciszek słusznie zauważa, że odpowiedzialność moralna poszczególnych osób za znalezienie się w sytuacji nieregularnej nie jest taka sama w każdym przypadku, co wyjaśnia, ilustrując różnymi przykładami (por. AL 298, nr 300 z odniesieniem do EG, nr 44 i 47). Ponadto wypływ okoliczności łagodzących może dodatkowo odpowiedzialność tę pomniejszać:

2 Tłumaczenie polskie adhortacji Amoris laetitia używa przymiotnika ,nieregularny” w odniesieniu do sytuacji. Natomiast tekst łaciński odnosi ten przymiotnik do przypadków, warunków, statusu. 
Kościół dysponuje solidną refleksją na temat uwarunkowań i okoliczności łagodzących. Dlatego nie można już powiedzieć, że wszyscy, którzy są w sytuacji tak zwanej ,nieregularnej”, żyją w stanie grzechu śmiertelnego, pozbawieni łaski uświęcającej. Ograniczenia nie zależą tylko od ewentualnej nieznajomości normy. Podmiot, choć dobrze zna normę, może mieć duże trudności w zrozumieniu „wartości zawartych w normie moralnej”, lub może znaleźć się w określonych warunkach, które nie pozwalają mu działać inaczej i podjąć inne decyzje bez nowej winy. Jak to dobrze powiedzieli Ojcowie synodalni, „mogą istnieć czynniki, które ograniczają zdolność podejmowania decyzji” (AL, nr 301).

Następnie papież w adhortacji cytuje fragmenty dokumentów Magisterium zawierających tradycyjne nauczanie o okolicznościach łagodzących (KKK, nr 1735 i 2352; Kongregacja Nauki Wiary 1980; RP, nr 17; Papieska Rada ds. Interpretacji Tekstów Prawnych 2000). Z dokumentów tych wynika, że czyny ludzkie mogą być dokonane w okolicznościach, które zmniejszają dobrowolność i tym samym odpowiedzialność moralną podmiotu działającego, a w konsekwencji także jego ewentualną winę za spowodowanie swoim czynem obiektywnego zła. Według papieża takie okoliczności powinny być uwzględniane $\mathrm{w}$ rozeznaniu duszpasterskim dotyczącym osób tworzących związek w sytuacji nieregularnej. Oznacza to, że w takich właśnie niestandardowych sytuacjach istnieć mogą okoliczności łagodzące odpowiedzialność moralną za spowodowanie takiego stanu rzeczy i trwanie w nim. Jedną z takich okoliczności jest, zdaniem autora adhortacji, niemożność wycofania się z nielegalnego związku bez potęgowania zła, co sprawia, że trudno jest w takiej sytuacji działać inaczej (por. AL, nr 302).

Niejednoznacznie, lecz w sposób domyślny tekst adhortacji Amoris laetitia wydaje się odnosić nauczanie o okolicznościach łagodzących także do współżycia seksualnego pomiędzy osobami tworzącymi związek znajdujący się w sytuacji nieregularnej. Na mocy nauczania samego Chrystusa Kościół tradycyjnie postrzega takie pozamałżeńskie współżycie pomiędzy osobami, z których przynajmniej jedna jest związana węzłem małżeńskim, jako grzech cudzołóstwa (por. Mt 5,32; 19,9; Mk 10,11-12; Łk 16,18; por. także KKK, nr 2380). Jest to grzech ciężki, który uniemożliwia odziedziczenie królestwa Bożego (por. 1 Kor 6,9-10). Jednak tekst adhortacji dzięki zastosowaniu tradycyjnej nauki o okolicznościach łagodzących do tego rodzaju czynów wydaje się wyrażać intencję pomniejszania ich grzesznego charakteru i ciężkości. Intencja ta nie jest zakomunikowana wyraźnie z jednoznacznością i precyzją właściwą dla dokumentów doktrynalnych i prawnych. Można się jej jednak domyślać na podstawie realiów życia, które pokazują, że mężczyzna i kobieta, decydując się na wspólne zamieszkanie i życie, najczęściej ze sobą współżyją seksualnie. Domniemywa to np. prawo kanoniczne w odniesieniu do ana- 
logicznego życia wspólnego małżonków, a Katechizm Kościoła katolickiego w odniesieniu do powtórnego związku rozwodników ${ }^{3}$. Na pierwszy rzut oka można by nawet mieć wątpliwości, czy rzeczywiście w tekście adhortacji chodzi także o akty seksualne pomiędzy osobami tworzącymi związek znajdujący się w sytuacji nieregularnej. Właściwie, gdyby nie przypis 329 , to tematyka współżycia w ogóle nie pojawiłaby się w rozdziale ósmym, dotyczącym związków w sytuacjach nieregularnych. Nawet jednak w tym przypisie papież porusza to zagadnienie nie wprost, używa języka delikatnego, metaforycznego, wolnego od wartościowania moralnego. Raczej prezentuje egzystencjalny i socjologiczny opis poważnej trudności, jakiej doświadczają osoby pozostające w związku pozamałżeńskim i powstrzymujące się od współżycia, natomiast nie wyraża w tym miejscu swojego własnego nauczania. Poza tym, gdyby papieżowi w ogóle nie chodziło o kwestię współżycia seksualnego pomiędzy osobami tworzącymi związek nielegalny, to nie byłoby w ogóle potrzeby poruszać zagadnienia okoliczności łagodzących, a sama adhortacja nie wzbudzałaby tylu kontrowersji. Dotychczasowe bowiem nauczanie Kościoła i praktyka duszpasterska dopuszczały, aby osoby trwające w związku nieprawym dla dobra potomstwa lub innej słusznej przyczyny mieszkały wspólnie, tworząc rodzinę naturalną, pod warunkiem jednak, że będą żyły ,jak brat z siostrą", zupełnie powstrzymując się od współżycia seksualnego, do którego nie mają prawa i które w ich przypadku byłoby ciężkim grzechem cudzołóstwa (por. FC, nr 84; Kongregacja Nauki Wiary 1994). Jeśli warunek ten byłby spełniony, wówczas takie osoby mogłyby przystępować do Komunii Świętej.

Tymczasem novum prezentowanym w adhortacji Amoris laetitia, budzącym skrajne reakcje, jest właśnie rozszerzenie tej możliwości przyjmowania sakramentów i objęcie nią także takich osób, które znajdują się w podobnych sytuacjach, lecz nie spełniają warunku wstrzemięźliwości seksualnej i nie żyją ,jak brat i siostra". Świadczy o tym także interpretacja adhortacji dokonana przez argentyńskich biskupów regionu Buenos Aires (zwłaszcza jej nr 6 skontrastowany z nr. 5), której trafność papież potem potwierdził, określając ją jako interpretację w pełni wyrażającą znaczenie rozdziału ósmego, obok której nie ma innych interpretacji (por. AL, nr 300). Praktyczne rozwiązanie promowane przez papieża ma mieć charakter ograniczony, gdyż dopuszczenie do Komunii

${ }^{3}$ Por. KPK kan. 1061 § 2: „Gdy po zawarciu małżeństwa małżonkowie wspólnie zamieszkali, domniemywa się dopełnienie, dopóki coś przeciwnego nie zostanie udowodnione”. Por. także: KKK, 2384 cytujący św. Bazylego, Moralia, reguła 73: PG 31, 849 D - 853 B: „Fakt zawarcia nowego związku, choćby był uznany przez prawo cywilne, powiększa jeszcze bardziej ciężar rozbicia; stawia bowiem współmałżonka żyjącego w nowym związku w sytuacji publicznego i trwałego cudzołóstwa: «Jeśli mąż, odłączywszy się od swej żony, łączy się z inną kobietą, sam jest cudzołożnikiem, ponieważ każe popełnić cudzołóstwo tej kobiecie; także kobieta, która mieszka z nim, jest cudzołożnicą, ponieważ pociągnęła do siebie męża innej kobiety»”. 
Świętej osób żyjących w związkach nieprawych, z których nie są w stanie się wycofać bez generowania dodatkowego zła, nie może się odbywać standardowo, lecz wyłącznie w wyniku roztropnego rozeznania duszpasterskiego. Jednak szczegółowych kryteriów wspomnianego rozeznania papież nie formułuje, gdyż - jego zadaniem - takie sytuacje „nie powinny być skatalogowane” (AL, nr 298). Dlatego istnieje uzasadniona obawa, że przedstawionym przez papieża rozwiązaniem, którego zakres zastosowania jest nieostry, w praktyce będzie można objąć wszystkie trwałe związki pozamałżeńskie, pod warunkiem, że nie afiszują się z obiektywnym grzechem i wypełniają obowiązki życia rodzinnego (por. AL, nr. 297-298). Takie możliwości interpretacji i aplikacji papieskiego rozwiązania dostrzegają zarówno jego zwolennicy, jak i przeciwnicy, tyle tylko, że dla tych pierwszych jest to powód do radości, dla tych drugich zaś do smutku.

Podejmując tradycyjne nauczanie o okolicznościach łagodzących, zmniejszających winę osób współżyjących seksualnie w związku nielegalnym, papież Franciszek nie wyjaśnia dalej w kategoriach teologicznomoralnych, jak miałby ten wpływ okoliczności łagodzących wyglądać. Można się jednak domyślać, że przy istnieniu okoliczności łagodzących grzech cudzołóstwa, pomimo swej ciężkiej materii, albo pozostawałoby tylko grzechem lekkim, który - jak wiadomo - może być odpuszczony nawet bez sakramentalnej spowiedzi dzięki wzbudzeniu aktu żalu doskonałego, albo też pozostawałby wprawdzie nadal grzechem ciężkim, który jednak ze względu na trudność jego uniknięcia i na niemożliwość rozejścia się bez potęgowania dalszej winy, mógłby podlegać odpuszczeniu w wyniku udzielenia absolucji podczas sakramentalnej spowiedzi, jeśli tylko grzesznik żałuje i obiecuje poprawę. Jednocześnie papież Franciszek przypomina nauczanie św. Jana Pawła II, według którego: „przewidywalność nowego upadku «nie przesądza o autentyczności postanowienia»" (Jan Paweł II 1996, s. 589; AL, przyp. 364).

Okoliczności łagodzące w adhortacji Amoris laetitia funkcjonują w powiązaniu z tzw. „prawem stopniowości”, które za Janem Pawłem II Franciszek odróżnia od tzw. „stopniowości prawa”. Stopniowość prawa to błąd, odrzucony przez obydwu tych papieży, polegający na relatywizacji prawa Bożego, ,jak gdyby w prawie Bożym miały istnieć różne stopnie i formy nakazu dla różnych osób i sytuacji” (FC, nr 34). Wydaje się więc, że stopniowość prawa $\mathrm{w}$ praktyce oznaczałaby pluralizm różnych zakresów tego samego prawa dla różnych osób, tak jakby każdy z tych zakresów gwarantował osiągnięcie wystarczającego celu i zapewniał człowiekowi w wystarczającym stopniu spełnienie i szczęście. Natomiast prawo stopniowości to fenomen życia moralnego, polegający na tym, że różne osoby realizują jedno, obiektywne i wspólne dla wszystkich prawo Boże i jeden cel ostateczny na miarę swoich aktualnych możliwości, usiłując jednocześnie stopniowo przekraczać swoje osobiste 
ograniczenia i realizować prawo Boże jak najpełniej, przy ich osobistej ufnej współpracy z łaską Bożą (por. AL, nr 295).

Wzywając do duszpasterskiego rozeznania i towarzyszenia osobom dążącym do realizacji ideału chrześcijańskiego, papież Franciszek świadom jest możliwych nadużyć, jakie mogą pojawić się na tej drodze, przed którymi wyraźnie przestrzega. Podkreśla, że:

rozeznanie nigdy nie może nie brać pod uwagę wymagań ewangelicznej prawdy i miłości proponowanej przez Kościół [...] że nie można stawiać swoich pragnień ponad dobro wspólne Kościoła, że należy unikać myślenia, iż Kościół popiera podwójną moralność (AL, nr 300).

Papież dodaje także, że:

jeśli ktoś afiszuje się z obiektywnym grzechem tak, jakby był częścią ideału chrześcijańskiego, czy chciałby narzucić coś innego od tego, czego naucza Kościół, to nie może domagać się, by uczyć katechizmu czy przepowiadać, i w tym sensie istnieje coś, co go oddziela od wspólnoty (por. Mt 18,17) (AL, nr 297).

Omawiając okoliczności łagodzące jako na czynnik pomniejszający odpowiedzialność moralną, domyślnie także za grzechy cudzołóstwa, jakie zgodnie $\mathrm{z}$ tradycyjnym nauczaniem mają miejsce pomiędzy osobami tworzącymi związek nieregularny, papież Franciszek przywołuje autorytet teologiczny św. Tomasza z Akwinu, aby uzasadnić nim możliwość obdarowania miłosierdziem Bożym i łaską takich osób, pomimo obiektywnego nieporządku tkwiącego w ich wzajemnym pożyciu. W związku z tym papież pisze, że:

Św. Tomasz z Akwinu uznał, że ktoś może posiadać łaskę i miłosierdzie, ale może nie wypełniać którejkolwiek z cnót, tak, że nawet posiadając wszystkie wlane cnoty moralne nie ukazuje wyraźnie istnienia żadnej z nich, ponieważ zewnętrzne działanie tej cnoty napotyka na trudność: „kiedy powiada się, że niektórzy święci nie posiadali pewnych cnót, to jednak mieli sprawności wszystkich cnót" (AL, nr 301 z odniesieniem do Tomasz z Akwinu 1891-1897, I-II, q. 65, a. 3 ad 2-3; De Malo, q. 2, a. 2).

Warto jednak zauważyć, że brak aktów posiadanej cnoty, spowodowany niemożnością ich dokonania na skutek zewnętrznych ograniczeń działania, nie jest tym samym, co brak aktów cnoty spowodowany brakiem cnoty. Święty Tomasz w cytowanym fragmencie pisze o pierwszej ze wspomnianych możliwości, mianowicie tej, gdzie brak aktów posiadanej cnoty spowodowany jest niemożnością ich dokonania na skutek zewnętrznych ograniczeń działania. Wydaje się natomiast, że papież w adhortacji rozciąga ten stan rzeczy i w nie- 
zrozumiały sposób włącza do niego także te osoby, u których brak aktów cnót jest spowodowany brakiem cnót. Dlatego takie posługiwanie się cytowaną myślą św. Tomasza można by uznać za nadużycie, gdyż intencja św. Tomasza zdaje się zupełnie inna od intencji, z jaką jego wypowiedź cytowana jest w adhortacji Amoris laetitia. Jednak, ściśle rzecz biorąc, tego typu nadużycie nie jest drogą rozumowania, którą podjął papież Franciszek. Zanim bowiem papież zrobił użytek z tej myśli Tomasza, najpierw dzięki okolicznościom łagodzącym zmienił status cudzołóstwa w związkach nieregularnych z grzechu śmiertelnego, uniemożliwiającego życie w łasce Bożej i posiadanie cnót, na grzech lekki, który nie pozbawia człowieka łaski i miłości Bożej oraz nie uniemożliwia rozwoju cnót (por. RP, nr 17; KKK, nr 1863; Tomasz z Akwinu 1891-1897, I-II, q. 72, a. 5). W związku z tym, zdaniem papieża, z racji występowania okoliczności łagodzących „nie można już powiedzieć, że wszyscy, którzy są w sytuacji tak zwanej «nieregularnej», żyją w stanie grzechu śmiertelnego, pozbawieni łaski uświęcającej” (AL, 301; por. także AL, nr 305), to znaczy, że takie osoby mogą mieć łaskę a wraz z nią cnoty wlane, których nie mogą tylko przejawiać, na skutek ograniczeń w zewnętrznym działaniu.

Podsumowując, wydaje się, że można by w następujący sposób zrekonstruować przebieg wywodu w adhortacji Amoris laetitia:

1) Rozwód i zawarcie drugiego związku są wyraźnie sprzeczne z ewangelicznym ideałem, jednak mogące wystąpić w tej sytuacji okoliczności łagodzące redukują winę, a wówczas pożycie seksualne osób tworzących taki związek nie musi już być śmiertelnym grzechem cudzołóstwa, gdyż chroniąc wzajemną wierność pomiędzy nimi, przyczynia się do dobra ich potomstwa.

2) Jeśli nawet $\mathrm{w}$ takim pożyciu seksualnym pozostawałby jeszcze jakiś nieporządek, to byłby to już tylko grzech lekki, a taki grzech ani nie pozbawia łaski, wraz z którą wlane są cnoty, ani nie podlega obowiązkowi wyznania podczas sakramentalnej spowiedzi.

3) W ten sposób osoby tradycyjnie postrzegane za cudzołożników, z powodu okoliczności łagodzących, przedstawione są w adhortacji jako osoby cnotliwe, które jedynie w wyniku zewnętrznych ograniczeń nie mogą dokonywać wszystkich aktów posiadanych przez siebie cnót.

4) Skoro trwanie w takim stanie nie musi stanowić grzechu ciężkiego, lecz może być jedynie grzechem lekkim, i skoro zgodnie z porządkiem kanonicznym nie ma obowiązku spowiadania się z grzechów lekkich (por. KPK kan. 988), to można wówczas przystępować do Komunii Świętej (por. Sobór Trydencki 2004, Sesja XIII, Dekret o Sakramencie Eucharystii, rozdz. 7 [DS 1657], Kanony o Sakramencie Eucharystii, kan. 11 [DS 1661]; KPK, kan. 916; KKK, nr 1457), która - jak przypomina papież - nie jest nagrodą, lecz zgodnie z tradycją jest też lekarstwem 
i pokarmem dla słabych (por. EG, 47; KKK, nr 1212, 1244, 1331, 1355, 1383, 1392-1394, 1405 wraz $\mathrm{z}$ odniesieniem do tekstów patrystycznych).

5) Tym samym w takim związku nie jest bezwzględnie wymagane zaniechanie współżycia seksualnego i może być ono tolerowane dla dobra utworzonej w jego wyniku rodziny naturalnej.

Wydaje się więc, że w adhortacji Amoris laetitia rozwiązanie przedłożone przez papieża Franciszka nie jest sprzeczne z dotychczasową doktryną i z doktryny tej wydobywa i eksponuje obecną w niej tradycyjną naukę o okolicznościach łagodzących, pomniejszających ciężkość grzechu. Takie rozwiązanie nie narusza ani nauki głoszącej, że seksualne współżycie pozamałżeńskie jest grzechem cudzołóstwa, ani nauki, zgodnie z którą ten, kto przyjmuje Komunię Świętą niegodnie (czyli w stanie grzechu ciężkiego), popełnia grzech świętokradztwa (por. 1 Kor 11,27-29; KKK, 2120), ani też nie godzi w naukę o czynach wewnętrznie złych, które pozostają złe zawsze i wszędzie, których żadne okoliczności nie mogą zamienić w czyny moralnie dopuszczalne i które w związku z tym pozostają zakazane absolutnymi zakazami moralnymi, niedopuszczającymi wyjątków. Dzięki takiemu zabiegowi w adhortacji Amoris laetitia zostaje uzyskany efekt umożliwiający zmianę obecnej praktyki i dyscypliny kościelnej, bez - jak wolno przypuszczać - naruszania doktryny. Zaprezentowane w tej adhortacji rozwiązanie dyscyplinarne jest jednak ewidentnie odmienne od tego, które było wyrażone w poprzednich dokumentach i obowiązywało dotychczas (AL, nr 305, przyp. 351).

\section{Problemy z koncepcją okoliczności lagodzących w adhortacji Amoris laetitia}

Takie rozwiązanie, z pozoru niesprzeczne $\mathrm{z}$ dotychczasową doktryną, ma jednak dość istotny mankament. Mianowicie, wydaje się, że w adhortacji rola okoliczności łagodzących jest przedstawiona w taki sposób, jakby wypływała z legalistycznej wizji moralności. Legalizm to postawa intelektualna, według której istnieje prymat normy nad dobrem. Dla legalisty norma jest źródłem dobra, a nie odwrotnie. Legalista postrzega określone działanie jako dobre, ponieważ jest ono nakazane, inne zaś jako złe, ponieważ jest zakazane. Tymczasem właściwy porządek rzeczy jest odwrotny: określone działanie jest nakazane lub zalecane, ponieważ jest dobre, inne natomiast jest zakazane, ponieważ jest złe. Legalista nie przyjmuje więc, że źródłem normy jest dobro i unikanie zła (por. Piechowiak 2005, s. 286-289). Legalizm jest postawą, która może cechować zarówno podejście do prawa stanowionego, jak i prawa moralnego. Dla osoby o mentalności legalistycznej liczy się przede wszystkim 
wewnętrzna spójność całego systemu prawa, stanowiąca ramy dla interpretacji jego norm. Oczywiście nie każda interpretacja norm i ich stosowanie do poszczególnych przypadków ma charakter legalistyczny tylko dlatego, że kieruje się koherencją całego systemu prawa. Trudno sobie wyobrazić, aby było inaczej i aby można było zignorować wymaganie spójności systemu w dziedzinie interpretacji i specyfikacji norm. Taka interpretacja jest jednak zasadna pod warunkiem, że nie chodzi w niej wyłącznie o wewnątrzsystemową koherencję norm i o spójne stosowanie ich w analogicznych przypadkach. Właściwa interpretacja prawa kieruje się także kryterium spójności poszczególnych norm i całego ich systemu z dobrem, które jest uprzednie wobec prawa i stanowi rację prawa. Legalistyczna jest dopiero taka interpretacja, która pomija kryterium spójności prawa z pierwotną racją dobra i kieruje się wyłącznie wewnętrzną formalną koherencją systemu norm oraz ich spójnym stosowaniem w analogicznych przypadkach.

Legalizm może mieć swą wersję rygorystyczną, cechującą się maksymalizmem i drobiazgowością w przestrzeganiu wszystkich przepisów prawa, nawet jeśli w wyjątkowych sytuacjach niektóre z nich są nieadekwatne, gdyż nie służą prawdziwemu dobru. Legalizm może też przybrać formę laksystyczną dążącą do minimalizmu $\mathrm{w}$ przestrzeganiu przepisów prawa i do zwalniania się nawet z tych, które rzeczywiście służą prawdziwemu dobru. Jeden z tych typów legalizmu może pojawić się czasem jako swoista opozycja wobec drugiego typu. Dokonało się to, zdaniem niektórych badaczy i obserwatorów, po Soborze Watykańskim II w dziedzinie legalistycznie i powinnościowo zorientowanej teologii moralnej, gdzie laksystyczne podejście pojawiło się jako sposób odreagowania przedsoborowego rygoryzmu (por. Chaput 2017; Pinckaers 1994, s. 279-281).

W dziedzinie prawa moralnego i stanowionego okoliczności łagodzące zmniejszają zupełnie lub częściowo winę osoby naruszającej normę prawa i sprawiają, że winy tej się zupełnie nie poczytuje lub poczytuje się ją jedynie w mniejszym stopniu. Jeśli jednak nawet w wyniku okoliczności łagodzących nie można zupełnie sprawcy zła przypisać odpowiedzialności moralnej lub karnej, to mimo to spowodowane przez niego rzeczywiste zło zostało dokonane i nie można utrzymywać, że w związku z występowaniem okoliczności łagodzących nic złego się nie stało. Brak poczytalności i winy nie jest równoznaczny z brakiem zła. Zło wprawdzie nie ma wówczas charakteru moralnego czy karnego, ale pozostaje złem na poziomie ontycznym i egzystencjalnym. Na przykład, jeśli ktoś prowadzi samochód i z powodu nagłego pogorszenia warunków atmosferycznych i ograniczonej widoczności doprowadza do wypadku, zabijając człowieka, to nikt przy zdrowych zmysłach nie będzie twierdził, że nic złego się nie stało, bo sprawca nie uczynił tego celowo i wystąpiły okoliczności łagodzące. Raczej taki kierowca zastanowi się, jak ma 
postępować w przyszłości, aby zapobiec tego typu możliwym nieszczęśliwym wypadkom i nie wystarczy mu w takiej sytuacji poprzestawanie na własnej niewinności. $Z$ takich zdarzeń należy wyprowadzić wniosek, aby w przyszłości unikać tego, co może prowadzić do zła, żeby takie sytuacje się już więcej nie powtórzyły. Dla kogoś jednak, kto rozumuje w sposób czysto legalistyczny, skoro w jakimś przypadku występują stosowne okoliczności łagodzące, to przekroczenie normy osądza się jako stosunkowo niewielkie i zaradza mu się odpowiednim zadośćuczynieniem, opłacającym się sprawcy w ostatecznym rozrachunku, albo nawet przekroczenia normy w ogóle się nie poczytuje i traktuje się je jako nieistniejące. W tym ostatnim przypadku okoliczności łagodzące sprawiają, że czyn powodujący szkodę nie pociąga za sobą żadnych skutków prawnych, stąd całą sprawę legalista traktuje w taki sposób, jakby nic się nie stało. Wówczas zgodnie z legalistyczną interpretacją prawa nic nie stoi na przeszkodzie, aby dalej tak postępować, nie trzeba wyprowadzać żadnego wniosku na przyszłość, aby unikać analogicznych sytuacji, chyba że w międzyczasie ustawodawcy, kierujący się prawdziwym dobrem, znowelizują prawo i zadbają o lepszą ochronę dobra, uniemożliwiając jego bezkarne naruszanie w imię legalistycznych interpretacji prawnych.

W każdym porządku, zarówno prawa moralnego, jak i prawa stanowionego, legalizm jest zjawiskiem szkodliwym, bo odrywa te porządki od prawdziwego dobra, któremu powinny one ze swej natury służyć, regulując ludzkie postępowanie. Ponieważ w niniejszych rozważaniach, poświęconych okolicznościom łagodzącym w adhortacji Amoris laetitia, interesuje nas bardziej porządek moralny, dlatego postawę legalizmu będziemy dalej omawiać głównie w odniesieniu do moralności, z wykorzystaniem pewnych analogii do systemu kościelnego prawa stanowionego. Naszym zdaniem bowiem, rola okoliczności łagodzących w odniesieniu do osób tworzących związki pozostające w sytuacjach nieregularnych została przedstawiona adhortacji Amoris laetitia w sposób legalistyczny, z poszanowaniem wewnętrznej formalnej spójności norm i innych elementów nauczania moralnego, lecz ostatecznie w oderwaniu od prawdziwego dobra. W porządku moralnym legalistyczna interpretacja okoliczności łagodzących jest nadużyciem, które prowadzi do szkodliwego minimalizmu moralnego, a ostatecznie do wypaczenia natury samej moralności.

Nawet jeśli w wyniku okoliczności łagodzących określona osoba w ogóle nie odpowiada moralnie za zło, które wyrządziła, to jednak nie znaczy, że nic się nie stało i że w takich okolicznościach można tak dalej postępować. Byłoby to równoznaczne z przyzwoleniem na dokonywanie zła w imię okoliczności łagodzących. W ten sposób zamiast pomóc ludziom żyć moralnie dobrze, bo tylko moralna dobroć gwarantuje osiągnięcie spełnienia ludzkiego życia i szczęścia, okoliczności łagodzące służyłby jako sposób uwolnienia ludzi od wymagań prawa moralnego, jak gdyby było ono dla nich przeszkodą na drodze do speł- 
nienia i szczęścia. Poza tym okoliczność, której adhortacja przypisuje dominujące znaczenie łagodzące, a którą jest zrodzenie potomstwa i związane z tym stanem rzeczy obowiązki naturalne, powodujące, że nie można się już wycofać z takiego związku bez zaciągania dodatkowej winy, jest okolicznością, która była wcześniej do przewidzenia i została spowodowana w sposób zawiniony działaniami, z których można się było uprzednio wycofać. Jeśli więc człowiek ponosi konsekwencje swoich złych czynów, to trudno uznać te konsekwencje za okoliczności łagodzące moralną odpowiedzialność i sprawiające, że kontynuacja grzesznego stanu życia staje się z tego powodu moralnie dopuszczalna. Dlatego łagodzący wpływ tej okoliczności jest kontrowersyjny. Wprawdzie sprawia ona, że moralnie dopuszczalne (choć nienakazane) staje się trwanie w związku dla dobra utworzonej z niego rodziny naturalnej i tolerowanie wygenerowanej w ten sposób okazji do grzechu, natomiast nadal niedopuszczalne pozostaje popełnianie grzechów cudzołóstwa. Chociaż niepopełnianie grzechów cudzołóstwa w sytuacji wspólnego zamieszkania, spowodowanego odpowiedzialnością za wychowywanie potomstwa, jest bardzo trudne, to przecież jest możliwe, dlatego Kościół powinien do tego nieustannie zachęcać i przynaglać, i nie wprowadzać rozwiązań promujących rezygnację z życia moralnie dobrego i pozbawiających nadziei na takie życie. Żadne okoliczności łagodzące nie dają moralnego mandatu na kontynuowanie popełniania zła. Uwalniają one od winy, ale nie uwalniają z wysiłków wystrzegania się zła.

Dzięki legalistycznej interpretacji okoliczności łagodzących w adhortacji Amoris laetitia formalnie udaje się uniknąć odrzuconego przez Kościół błędu proprocjonalizmu i błędu opcji fundamentalnej poprzez obejście głoszonej przez Kościół nauki o czynach wewnętrznie złych, nawet o nich nie wspominając, czy „zneutralizowanie” jej. Przez taki manewr w dokumencie papieskim został osiągnięty ten sam efekt praktyczny, na którym zależało proporcjonalistom i zwolennikom opcji fundamentalnej, podważającym naukę o czynach wewnętrznie złych ${ }^{4}$. Przypomina to podobny zabieg, dokonany w dziedzinie prawa kanonicznego, i skutkujący „zneutralizowaniem” ekskomuniki latae sententiae za przestępstwo aborcji. Papież Franciszek bowiem udzielił bezterminowo władzy uwalniania od tej cenzury wszystkim spowiednikom ${ }^{5}$, dzięki czemu bez spełniania jakichkolwiek dodatkowych wymagań osoba, która

\footnotetext{
${ }^{4}$ Papież Jan Paweł II określił jako błędne koncepcje tzw. opcji fundamentalnej i proporcjonalizmu w encyklice Veritatis splendor, 65-70, 7475, 79, 90 (por. także Sobór Trydencki 2004, sesja VI, Dekret o usprawiedliwieniu, rozdz. 15 [DS 1544], Kanony o usprawiedliwieniu, kan. 27 [DS 1577]; RP, nr 17).

${ }^{5}$ Najpierw papież Franciszek wprowadził takie rozwiązanie na okres nadzwyczajnego Jubileuszu Miłosierdzia w Liście, na mocy którego udziela się odpustu z okazji Jubileuszu Miłosierdzia (1-IX-2015), a potem utrzymał je w mocy bezterminowo w Liście Apostolskim Misericordia et misera, nr 12 (20-XI-2016), wydanym na zakończenie Jubileuszu Miłosierdzia.
} 
popełniła przestępstwo aborcji, może obecnie łatwo otrzymać rozgrzeszenie, praktycznie tak samo łatwo, jakby ta cenzura w ogóle nie istniała. Taki zabieg, podyktowany niewątpliwie szlachetną pobudką okazywania miłosierdzia wobec grzeszników, jest jednak ostatecznie wymierzony przeciwko poprawczemu charakterowi samej cenzury i tym samym przeciwko racji jej istnienia $\mathrm{w}$ prawie. $\mathrm{W}$ ten sposób bowiem zostało także osłabione znaczenie aborcji, która formalnie nie straciła statusu przestępstwa kanonicznego, ale de facto obecnie jest traktowana w taki sposób, jakby nie była już przestępstwem, lecz „zwyczajnym” grzechem ciężkim.

Analogiczny efekt został uzyskany w adhortacji Amoris laetitia w dziedzinie nauczania moralnego. Papież bowiem nie zaprzeczył niczemu ani nie wyeliminował niczego z dotychczasowego nauczania moralnego Kościoła, a zwłaszcza nie naruszył formalnie nauki o czynach wewnętrznie złych zabronionych absolutnymi zakazami moralnymi. Dzięki jednak legalistycznej interpretacji okoliczności łagodzących, którą wydaje się prezentować papieski dokument, nauka ta ulega niejako obejściu czy zneutralizowaniu. Dlatego w świetle tej adhortacji współżycie seksualne w związku pozamałżeńskim, które nie straciło statusu czynu wewnętrznie złego, w praktyce na skutek wpływu legalistycznie zinterpretowanych okoliczności łagodzących, może być tolerowane jako jedynie akt popełniany bez poważnej winy moralnej, której miara nie przeszkadza w życiu łaską Bożą.

Tak więc „neutralizacja” zarówno ekskomuniki latae sententiae za przestępstwo aborcji, jak i czynów wewnętrznie złych zakazanych absolutnymi zakazami moralnymi, choć nie usuwa tych elementów z właściwych im porządków, którymi są odpowiednio porządek kanoniczny i porządek moralny, to jednak uniemożliwia ich funkcjonowanie w tych porządkach, co ostatecznie jest sprzeczne $\mathrm{z}$ ich racją istnienia $\mathrm{w}$ odpowiadających im porządkach $\mathrm{i} \mathrm{w}$ opisujących je naukach. Pomimo znacznego podobieństwa, jakie występuje pomiędzy obejściem czy neutralizacją ekskomuniki latae sententiae za przestępstwo aborcji w dziedzinie prawa kanonicznego a legalistycznym obejściem czy neutralizacją czynów wewnętrznie złych i absolutnych zakazów moralnych w dziedzinie moralności, zachodzi pomiędzy nimi istotna różnica. $\mathrm{O}$ ile bowiem nad słusznością rozwiązań i przepisów prawa stanowionego można debatować i można je potem zmieniać, odwołując poprzednie rozwiązania, gdyż nie są one ustanawiane raz na zawsze w sposób nieomylny, o tyle prawda moralna jako taka nie może podlegać zmianom i odwołaniu. Można dyskutować nad jej konkretnymi teoretycznymi ujęciami czy sformułowaniami, ale z natury uniwersalnej prawdy wynika, że to, co było prawdziwe kiedyś, musi być prawdziwe także dzisiaj i odwrotnie. Rozwiązanie polegające na obejściu jakiegoś elementu i jego neutralizacji w dziedzinie prawa stanowionego może doprowadzić do jego zepsucia lub ulepszenia. Natomiast w dziedzinie moralności i jej 
prawdziwego ujęcia w doktrynie Kościoła rozwiązania omijające lub neutralizujące poszczególne elementy prawdy moralnej prowadzą do dysfunkcji całej doktryny, a w konsekwencji do dysfunkcji i rozkładu samej moralności.

Jeśli okoliczności łagodzące działałyby w taki legalistyczny sposób, który - jak można przypuszczać - jest zastosowany w adhortacji Amoris laetitia w odniesieniu do współżycia seksualnego w powtórnym związku, to jaki sens miałaby jeszcze nauka Chrystusa o tym, że kto rozwodzi się i wiąże się $\mathrm{z}$ inną osobą - przy domniemaniu, że współżyje z nią seksualnie - ten popełnia cudzołóstwo? Okazuje się, że praktycznie żaden. Niby tekst adhortacji nie zaprzecza wprost tej nauce, ale zdając się stosować legalistyczną interpretację okoliczności łagodzących, neutralizuje jej wymowę i sprawia, że traci ona praktyczne znaczenie normy, a przybiera status ideału chrześcijańskiego, który - jak wiadomo - jest przedmiotem rady, a nie przykazania. Tymczasem św. Paweł w Pierwszym Liście do Koryntian wyraźnie uczy, że nierozerwalność małżeństwa jest przedmiotem przykazania Pańskiego, natomiast bezżenność dla królestwa niebieskiego jest wprawdzie stanem lepszym, ale jednocześnie stanowi przedmiot rady, a nie przykazania (por. 1 Kor 7,10.25). Co więcej, nie sposób sobie wyobrazić, aby Chrystus, który zna ludzkie serca i wie, co się w nich kryje (por. np. Mt 9,4; Mk 2,8; J 2,24-25; 12,11.21), oraz współczuje naszym słabościom (por. Hbr 4,15), nie był świadom trudności, na jakie zawsze w dziejach ludzkości jest wystawiana wzajemna wierność małżonków. Tymczasem mimo tej świadomości głosił On naukę o nierozerwalności małżeństwa i nie neutralizował jej w żaden sposób, lecz sam przeciwstawił się takiej neutralizacji, jaką dopuszczało prawo Mojżeszowe pod wpływem pewnych okoliczności, uznawanych za łagodzące (Mt 19,3-9). Jezus wyraźnie ukazywał nieodwołalny charakter pierwotnego zamysłu Stwórcy wobec małżeństwa i sam wyniósł małżeństwo do godności sakramentu, czyli widzialnego znaku Jego własnej miłości do Kościoła i tym samym widzialnego znaku niewidzialnej łaski Bożej wspierającej wzajemną jedność małżonków (por. Ef 5,31-32; KPK kan. 1055 § 1; KKK, nr 1601).

Co więcej, jeśli w legalistyczny sposób za pomocą okoliczności łagodzących można obejść absolutny zakaz moralny popełniania cudzołóstwa, które jest czynem wewnętrznie złym, to w ten sam sposób można obejść także wszystkie inne absolutne zakazy moralne, zabraniające popełniania innych czynów wewnętrznie złych. Jaki sens będzie miało wówczas wywodzące się z Pisma Świętego tradycyjne nauczanie Kościoła o tzw. czynach wewnętrznie złych, zakazanych absolutnymi zakazami moralnymi, niedopuszczającymi wyjątków? (por. 1 Kor 6,9-10; Sobór Trydencki, Sesja VI De iustificatione, rozdz. XV (DS 1544); KDK, nr 27; HV, nr 14; RP, nr 17; VS, nr 81; KKK, nr. 1753-1756). Przecież często przestrzeganie takich zakazów może się wydawać heroiczne, ponad siły zwyczajnego człowieka, i w wielu sytuacjach moż- 
na znaleźć jakieś dodatkowe okoliczności łagodzące, które w legalistycznym stylu zneutralizują wewnętrzne zło tych czynów i spowodują ich praktyczną dopuszczalność. Nie trzeba przy tym wcale zaprzeczać nauczaniu o czynach wewnętrznie złych i o absolutnych zakazach moralnych, nie trzeba tego nauczania odwoływać, wystarczy, jeśli się je zneutralizuje za pomocą legalistycznie zinterpretowanej roli okoliczności łagodzących. W krytyce legalistycznego nadużycia w powoływaniu się na wpływ okoliczności łagodzących nie chodzi oczywiście o podważanie każdego możliwego wpływu okoliczności łagodzących na moralną ocenę czynów ludzkich. Taki uzasadniony wpływ niewątpliwie może istnieć. Jeśli jednak moralna odpowiedzialność podmiotu działającego może być pod wpływem takich okoliczności znacznie ograniczona, i to nawet do minimum, nie powinno to przecież oznaczać przyzwolenia na styl życia polegający na popełnianiu czynów wewnętrznie złych, bo zło zawsze pozostaje złem i przeszkodą do osiągnięcia spełnienia i szczęścia człowieka.

Na przykład, według logiki legalistycznej neutralizacji czynów wewnętrznie złych i absolutnych zakazów moralnych za pomocą okoliczności łagodzących osoby homoseksualne, powołując się na okoliczność, jaką jest niezawiniona przez nie skłonność homoseksualna, będą mogły wymawiać się od winy za nieograniczone praktykowanie homoseksualizmu i porzucić starania o jakąkolwiek poprawę, gdyż ta, stanowiąc jedynie pewien ideał, nie będzie absolutnie konieczna i nakazana. Według tej logiki akty homoseksualne będą wówczas najwyżej grzechami lekkimi, z którymi osoby homoseksualne będą mogły przystępować do Komunii Świętej bez konieczności uzyskania z nich rozgrzeszenia w czasie sakramentalnej spowiedzi i bez związanego z tym postanowienia poprawy. Poza tym, skoro grzech lekki nie pozbawia łaski, wraz z którą wlane są cnoty, to w konsekwencji omawianego tu legalistycznego podejścia osoby współżyjące homoseksualnie będą mogły uchodzić za osoby cnotliwe, które jedynie z powodu zewnętrznych ograniczeń nie potrafią dokonywać wszystkich aktów posiadanych przez siebie cnót. Kontynuując to rozumowanie, można następnie zapytać: Cóż więc będzie stało na przeszkodzie w omawianym przypadku, aby takie osoby dla spełnienia swojego człowieczeństwa, powołanego przecież do miłości oblubieńczej i rodzicielstwa, adoptowały dzieci? Wówczas dla dobra swoich pociech będą wręcz zobowiązane, aby chronić i umacniać wzajemną wierność, a nic tak nie wystawia wierności tej na próbę i nie szkodzi dobru potomstwa, jak brak intymnego pożycia partnerów w takiej formie, w jakiej jest ono aktualnie możliwe - czyli w postaci aktów homoseksualnych. Jaki sens będzie miało jeszcze w takim przypadku nauczanie św. Pawła, o tym, że osoby współżyjące ze sobą i niepozostające ze sobą w związku małżeńskim nie odziedziczą królestwa Bożego (por. 1 Kor 6,9)? Praktycznie żaden. Niby nikt nie będzie zaprzeczał temu nauczaniu, ale $\mathrm{w}$ wyniku legalistycznej neutralizacji jego wymowy straci ono swoje praktyczne znaczenie. 
Legaliści nie rozumieją, że czyny wewnętrznie złe nie są złe dlatego, że zabrania ich absolutny zakaz moralny, ale odwrotnie: absolutny zakaz moralny zabrania takich czynów, ponieważ są zawsze złe, gdyż nigdy nie prowadzą do ludzkiego spełnienia i szczęścia, jakie daje realizacja celu ostatecznego, którym jest Bóg. Dlatego kwalifikacji moralnej czynów wewnętrznie złych nie da się zmienić przez legalistyczną modyfikację zabraniającej ich normy prawa moralnego. Skoro moralność ukazuje, w jaki sposób należy odpowiedzieć na najgłębsze pragnienia osoby ludzkiej, aby osiągnąć spełnienie, oraz stoi na straży dobra człowieka i jego godności, to legalistyczne próby wybronienia człowieka spod obowiązującej mocy norm prawa moralnego w gruncie rzeczy pozwalają człowiekowi na trwanie w tym, co jest sprzeczne z celem moralności, którym jest ludzkie dobro, spełnienie i szczęście. W konsekwencji legalizm, który broni człowieka przed odpowiedzialnością moralną za własne czyny i przed trudami życia moralnie dobrego, obraca się przeciwko samemu człowiekowi, pozbawiając go jego własnego spełnienia i szczęścia. Legalizm, abstrahując od rzeczywistości dobra, zakłada wypaczoną wizję moralności, jak gdyby nie wszyscy ludzie byli zdolni do życia moralnie dobrego i jakby wymagania moralne w życiu wielu z nich generowały jedynie uciążliwości i prowadziły do nieszczęścia, przed którym trzeba ich uchronić, omijając uciążliwe przepisy w sposób, na jaki pozwala system. Tymczasem, chociaż bez wątpienia różni ludzie urzeczywistniają cel moralności z różną „prędkością” i są zaawansowani w różnym stopniu na drodze jego realizacji, to jednak moralność jest jedna, obiektywna i wspólna dla wszystkich ludzi, a jej cel nie podlega stopniowaniu. Każdy człowiek, jeśli tylko chce być szczęśliwy, jest w stanie i powinien stopniowo przezwyciężać trudności w prowadzeniu życia moralnie dobrego „W spokojnej ufności w łaskę Bożą i we własną wolę" (FC, nr 34), gdyż poza życiem moralnie dobrym nie ma innej drogi wiodącej do szczęścia.

\section{Ryzykowne formy wsparcia ze strony nierzetelnie interpretowanych koncepcji}

W adhortacji Amoris laetitia legalistyczna interpretacja roli okoliczności łagodzących w ocenie moralnej czynów ludzkich funkcjonuje wśród innych swoiście zreinterpretowanych koncepcji i uzyskuje z nich dla siebie wsparcie. Wydaje się, że ten sposób $\mathrm{w}$ adhortacji niejako z różnych stron i przy udziale wielorakich środków dokonuje się neutralizacja tradycyjnej nauki o czynach wewnętrznie złych zabronionych absolutnymi zakazami moralnymi. Nauka ta bowiem jawi się jako niewygodna dla celu adhortacji, jakim jest dopuszczenie do Komunii Świętej osób żyjących w powtórnych związkach i współżyjących ze sobą, dlatego należało najpierw dokonać jakiejś jej adaptacji, aby 
cel ten osiągnąć. Skoro ta niewygodna nauka wywodzi się z tradycji, to nie da się jej zwyczajnie usunąć bez dokonywania wyłomu w doktrynie. W związku z tym wiele wskazuje na to, że nie przypadkiem w dokumencie zastosowano metodę czy wręcz strategię polegającą na neutralizacji niewygodnej nauki za pomocą argumentów pochodzących z tradycji, aby skutek neutralizacji był wiarygodny. Papież Franciszek odwołuje się bowiem w swojej adhortacji do poprzedniego nauczania Magisterium i do autorytetu św. Tomasza z Akwinu, aby podkreślić - jak wolno przypuszczać - że jego własne rozwiązanie pozostaje w zgodzie z tradycją. Przywołane w adhortacji pojęcia i koncepcje mogą sprawiać wrażenie tradycyjnych, jednak przy głębszej analizie okazuje się, że wcale nimi nie są. Różnią się one wyraźnie od swoich oryginalnych, tradycyjnych wersji i w związku $\mathrm{z}$ tym nie świadczą korzystnie o zakorzenieniu rozwiązania prezentowanego w adhortacji Amoris laetitia w dotychczasowej tradycji teologicznej i nauczaniu Kościoła. Co więcej, innowacyjne powoływanie się na tradycję sprawia wrażenie instrumentalnego preparowania argumentów i przemycania w tradycyjnym przebraniu rozwiązań $\mathrm{w}$ gruncie rzeczy radykalnie obcych tradycji. W dalszej części tego artykułu zwrócimy uwagę na kilka takich koncepcji, obecnych w tekście adhortacji.

\section{Nierozerwalność małżeństwa jako ideał, którego urzeczywistnianie podlega swoiście pojętemu prawu stopniowości}

Jan Paweł II, nauczając w kontekście małżeństwa o stosunku człowieka do prawa Bożego, z naciskiem podkreśla, że małżonkowie „nie mogą jednak patrzeć na prawo tylko jako na czysty ideał osiągalny w przyszłości” (tamże). Tymczasem Franciszek wiele razy w rozdziale ósmym swojej adhortacji przedstawia wskazania prawa właśnie jako ideał, z czego wynika, że niektóre z tych wskazań nie muszą być osiągalne dla wszystkich. Jednocześnie autor adhortacji Amoris laetitia nie precyzuje, czy ta niemożność osiągnięcia ideału może być tolerowana jedynie jako stan przejściowy, zajmujący jakiś skończony etap życia, czy raczej niemożność ta może być także cechą całego życia osób, dla których prawo do końca ich ziemskiej egzystencji pozostanie nieosiągalnym ideałem, wyznaczającym jedynie pewien kierunek zasadniczego życiowego dążenia. W ten sposób $\mathrm{w}$ adhortacji, przynajmniej w jakiejś mierze, dokonana została zamiana normy nakazującej nierozerwalność małżeństwa i normy zakazującej cudzołóstwa na ideał (por. AL, nr. 292, 298). Ideał zaś ma inną naturę niż norma. Ideał jest pewną szlachetną propozycją i nie ma mocy zobowiązującej. Jest przedmiotem wyzwania i rady, ale nie przykazania. Realizacja ideału jest czynem nadobowiązkowym, stąd brak tej realizacji nie jest grzechem. Ideał można komuś wskazywać, zachęcać do jego realiza- 
cji i aby to czynić lepiej, można towarzyszyć osobom wezwanym do realizacji ideału. Normy natomiast się naucza, ku jej przestrzeganiu wychowuje się człowieka i się jej wymaga, bo wskazuje ona, jak być powinno, i tym samym nakłada pewien obowiązek. Charakterystyczne jest właśnie to, że papież w adhortacji nie wzywa do nauczania i wymagania normy, ale wzywa duszpasterzy do towarzyszenia tym, którzy nie są w stanie w pełni realizować ideału. Obecna w adhortacji Amoris laetitia zamiana norm zakazujących rozrywania małżeństwa i zakazujących cudzołóstwa na ideały idzie $\mathrm{w}$ parze z zamianą rozumienia natury prawa moralnego. O ile Jan Paweł II eksponuje powinnościową naturę prawa, przynaglającą do wytrwałego przezwyciężania trudności (tamże), o tyle Franciszek podkreśla bardziej informacyjną naturę prawa, które nie przynagla i nie nakazuje, lecz jedynie wskazuje drogę i ją proponuje. Oczywiście charakterystyka informacyjna i powinnościowa prawa nie muszą się wcale wykluczać, lecz powinny się wzajemnie zakładać i uzupełniać. Jeśli bowiem prawo moralne wskazuje drogę do życia wiecznego, a odrzucenie wskazań prawa prowadzi do zatracenia, to racjonalny podmiot $\mathrm{z}$ tych wskazań potrafi przejść do tego, co powinien czynić i czego unikać, czyli potrafi wyprowadzić dla siebie powinności, bo nikt racjonalny nie wybierze przecież drogi prowadzącej do zatracenia. Dychotomia pomiędzy tymi dwiema drogami jest zresztą ideą na wskroś biblijną, którą posługuje się także sam Jezus (por. Pwt 30,15-20; Mt 7,13-14; J 15,5-6). Mogłoby się wydawać, że papież Franciszek chce zastosować tę samą metodę i eksponując informacyjną rolę prawa moralnego, liczy na to, że dojrzałe racjonalne osoby wyprowadzą z niego dla siebie powinności. $Z$ pewnością jednak nie ułatwia im tego zadania, twierdząc, niezgodnie z nauczaniem Jezusa, apostołów i Kościoła: „Nikt nie może być potępiony na zawsze, bo to nie jest logika Ewangelii! Nie mam na myśli tylko rozwiedzionych, żyjących w nowych związkach, ale wszystkich niezależnie od sytuacji, w jakiej się znajdują" (AL, nr 297) ${ }^{6}$. W przeciwieństwie do papieskich ustnych wypowiedzi podczas konferencji prasowych organizowanych w samolotach, adhortacja jest dokumentem starannie przygotowywanym, konsultowanym z ekspertami i redaktorami czuwającymi nad ścisłością znaczenia jej słów i właściwym odbiorem jej treści. Dlatego nie sposób oprzeć się wrażeniu, że brak wyważenia czy zniuansowania cytowanego powyżej twierdzenia, nie jest zwykłym przeoczeniem. Po co zatem iść idealną drogą wska-

\footnotetext{
${ }^{6}$ Nauczanie Jezusa, apostołów i Kościoła jest zupełnie inne - por. Mt 5,29-30 (por. Mk 9,43-48), Mt 13,24-30.36-43.47-50. 18,9-10. 25,41-46; J 5,28-29; Rz 1,32-2,12; 1 Kor 6, 9-11; Gal 5,19-21; Ef 5,5; 2 Tes 1,5-10, 1 P 4; 17-18; Ap 21,8; BD (29-I-1336 r., DS. 1002); KKK, nr. 1033-1037. Pomimo realnej możliwości potępienia wiecznego, które jest sprawiedliwą odpłatą za czyny będące wyrazem świadomego i dobrowolnego odwrócenia się od Boga, Kościół uczy za św. Tomaszem z Akwinu, że: „o nikim nie można zwątpić w tym życiu, biorąc pod uwagę wszechmoc i miłosierdzie Boże" - Tomasz z Akwinu 1891-1897 II-II, q. 14, a. 3, ad 1; RP, nr 17.
} 
zaną przez prawo moralne, kiedy z góry wiadomo, że inne nieidealne drogi na pewno nie prowadzą do zatracenia, a w trakcie ich przemierzania też można realizować różne wartości?

Z dotychczasowego nauczania Kościoła wynika, że jedność i nierozerwalność jest dla małżeństwa normą, a nie ideałem, bo od niej zależy dobro małżeństwa i jego istnienie. Dlatego dbanie o tę nierozerwalność i zakaz jej naruszania ma także charakter obowiązku moralnego, a nie tylko wezwania czy zachęty. Ani zrozumienie bądź niezrozumienie wartości nierozerwalności, ani też trudność lub łatwość jej realizacji nie mają żadnego wpływu na jej normatywny i powinnościowy charakter i nie stanowią kryteriów rozróżnienia pomiędzy ideałem a normą. Z faktu bowiem, że jakaś wartość jest dla pewnych osób niezrozumiała lub trudna do realizacji, nie wynika, że jest ona ideałem. Na przykład w Kazaniu na górze Jezus nie tylko mówi o ideałach, ale mówi też o normach trudnych, które są możliwe do realizacji tylko dzięki Jego łasce. Podobnie jest $\mathrm{z}$ trudną normą nierozerwalności małżeństwa, realizowaną dzięki wsparciu łaski specjalnego sakramentu, do którego godności Chrystus Pan wyniósł małżeństwo.

Sprowadzenie przez papieża Franciszka absolutnej nierozerwalności małżeństwa i absolutnego zakazu współżycia seksualnego poza małżeństwem z poziomu obowiązującej normy do rangi nadobowiązkowego ideału sprawia, że także koncepcja prawa stopniowości jest w gruncie rzeczy inaczej rozumiana w adhortacji Amoris laetitia niż w oryginalnej wersji tej koncepcji przedstawionej przez Jana Pawła II w adhortacji Familiaris consortio (por. FC, nr 34). O ile w nauczaniu Jana Pawła II prawo stopniowości oznacza stopniowe przekraczanie własnych ograniczeń $\mathrm{w}$ dążeniu do osiągnięcia pełni realizacji normy prawa moralnego, a w związku z tym także pełni obowiązku moralnego, o tyle według interpretacji papieża Franciszka prawo stopniowości oznacza stopniowe przekraczanie własnych ograniczeń w dążeniu do osiągnięcia pełni nadobowiązkowego ideału moralnego. Konsekwentnie zatem w nauczaniu Jana Pawła II prawo stopniowości nakłada moralny obowiązek stopniowego dążenia do przestrzegania pełni normy moralnej na tych, którzy nie są w stanie od razu temu sprostać. Natomiast w modelu przedstawionym przez papieża Franciszka prawo stopniowości wskazuje takim osobom jedynie możliwość stopniowej realizacji pełni nadobowiązkowego ideału, do realizacji tej zachęca, jednak jej nie wymaga. Nie można przecież wymagać dorastania do tego, co jest nadobowiązkowe, a takimi przecież są ideały. Osoby skonfrontowane z ideałem nie muszą zatem starać się go realizować i mogą trwać w swoim nieidealnym stanie życia, zwłaszcza wtedy, kiedy odpowiednie okoliczności łagodzące dodatkowo redukują możliwą winę za czyny dokonane w takim stanie. Tym samym taka logika, która zdaje się przenikać tekst adhortacji Amoris laetitia, nie buduje u takich osób nadziei na poprawę, a ponadto zwalnia sa- 
mego papieża z odpowiedzialności za nauczanie normy i obowiązku jej przestrzegania.

Autor adhortacji Amoris laetitia twierdzi, że

sumienie może jednak uznać nie tylko to, że dana sytuacja nie odpowiada obiektywnie ogólnym postanowieniom Ewangelii. Może także szczerze i uczciwie uznać to, co w danej chwili jest odpowiedzią wielkoduszną, jaką można dać Bogu i odkryć z jakąś pewnością moralną, że jest to dar, jakiego wymaga sam Bóg pośród konkretnej złożoności ograniczeń, chociaż nie jest to jeszcze w pełni obiektywny ideał (AL, nr 303).

Małżeństwo jest przedstawione przez papieża Franciszka jako dobro, które jak każde dobro może być zrealizowane przez konkretne osoby bardziej lub mniej. W związku z tym zawsze należy się cieszyć nawet wówczas, kiedy dobro to jest realizowane choćby w skromniejszej formie, bo przecież także wówczas jest ono mimo wszystko dobrem. Tak rozumiana realizacja dobra, jakim jest małżeństwo, przypomina przymnażanie talentów w przypowieści o talentach (por. Mt 25,14-30). Przypowieść ta pokazuje, że godni pochwały są wszyscy słudzy, którzy przymnożyli otrzymane talenty, a nie tylko ten, który przymnożył ich najwięcej, bo przecież nie wszyscy otrzymali na początku tyle samo, więc nie wymaga się od nich, aby przymnożyli wszyscy po równo, lecz proporcjonalnie do tego, co otrzymali na początku. Podobnie jest z małżeństwem, gdzie godne pochwały są te osoby, które przymnożą miłość małżeńską tak dalece, jak to jest tylko możliwe w konkretnych okolicznościach ich życia, proporcjonalnie do ich początkowych możliwości, które nie są przecież równe u wszystkich.

Jednak analogia ta jest prawdziwa tylko pod pewnym względem. O ile bowiem dobro, jakim jest małżeństwo, może być urzeczywistniane w większym lub mniejszym stopniu, o tyle związek pomiędzy określonymi osobami nie może być bardziej lub mniej małżeństwem, tylko albo nim jest, albo nie jest. O ile doskonałości podlegają stopniowaniu, o tyle natura bytu nie podlega stopniowaniu. Podobnie też nie ma płynnego przejścia pomiędzy dobrem a złem poprzez jakieś pośrednie jakości aksjologiczne. Tymczasem na podstawie lektury tekstu adhortacji można odnieść wrażenie zacierania różnicy pomiędzy ciągłością i stopniowością realizacji dóbr małżeństwa a nieciągłością i niemożliwością stopniowania natury małżeństwa. Dlatego można odnieść wrażenie, że związki, które nie są małżeństwem, są traktowane w dokumencie papieskim tak, jakby w jakimś mniejszym stopniu nim były, ponieważ realizują dobra małżeństwa, tylko w mniejszym zakresie, ale nawet taką skromniejszą realizację wypadałoby docenić. Takie podejście, ku któremu skłania lektura adhortacji Amoris laetitia, wynika z postrzegania nauki Jezusa o małżeństwie 
jako ewangelicznego ideału. Stąd także związki w tzw. sytuacjach „nieregularnych" według tej koncepcji realizują ten ideał nie w pełni, lecz w jakimś mniejszym stopniu, który często stanowi maksimum, na jakie stać tworzące je osoby „pośród konkretnej złożoności ograniczeń” (AL, nr 303) i jakiego wymaga wówczas od nich Bóg, nie żądając niczego więcej. Co ciekawe, w swojej adhortacji papież Franciszek nie określa przymiotnikiem „nieregularny” samych związków, bo to wprowadzałoby nieciągłość pomiędzy związkami regularnymi a nieregularnymi i uniemożliwiło traktowanie małżeństwa jako rzeczywistości płynnej, bliższej lub dalszej ewangelicznemu ideałowi. Raczej jako nieregularne określone są jedynie sytuacje czy warunki zewnętrzne $\mathrm{w}$ różnym stopniu uniemożliwiające wielu związkom realizację pełni ideału małżeństwa. Poza tym, pisząc o związkach w tzw. sytuacjach nieregularnych, papież umieszcza przymiotnik „nieregularny” w cudzysłowie, a jednym z powodów takiego zabiegu może być fakt, że sytuacje określone jako nieregularne ze względu na uniemożliwienie pełnej realizacji ideału małżeństwa w wielu społeczeństwach są coraz bardziej regularne pod względem statystycznym.

Tymczasem, skoro prawdziwa natura małżeństwa nie jest ciągła i stopniowalna, to związki niespełniające istotnych cech małżeństwa, nie są małżeństwami. Skoro także różnica pomiędzy dobrem a złem nie jest płynna, to seksualne współżycie pozamałżeńskie, zgodnie z nauką Chrystusa, jest zawsze złe i nie ma jakiejś pośredniej jakości aksjologicznej. $Z$ tych powodów zarówno związek, jak i tworzące go akty współżycia pozamałżeńskiego nie mogą być „odpowiedzią wielkoduszną” i „darem, jakiego wymaga sam Bóg pośród konkretnej złożoności ograniczeń". Gdyby takie związki były akceptowaną formą relacji, a nawet „pośród konkretnej złożoności ograniczen” były wymagane przez Boga, to dlaczego Jezus tego nie uwzględnił w swojej polemice $\mathrm{z}$ faryzeuszami na temat małżeństwa i dlaczego współżycie seksualne w takich związkach nazwał cudzołóstwem? A skoro trudno zaprzeczyć, że nawet związki nieprawe realizują coś z dobra małżeństwa (np. wzajemną pomoc, wychowanie potomstwa), to przecież fakt ten nie usprawiedliwia popełniania zła (np. cudzołóstwa w takich związkach). Kościół zawsze uczył, że istnieją czyny złe same z siebie, których nigdy nie wolno rozmyślnie popełniać, aby wynikło z tego dobro (por. Sobór Trydencki, sesja VI, Dekret o usprawiedliwieniu, rozdz. 15 [DS 1544], Kanony o usprawiedliwieniu, kan. 27 [DS 1578]; KDK, nr 27; HV, nr 14; RP, nr 17; VS, nr 81; KKK, nr. 1753-1756; Augustyn, Contra Mendacium, cap. VII, 18 [PL 40, 528]; oraz liczne odniesienia w pismach św. Tomasza z Akwinu - por. poniżej), a nauka ta ma podstawy w Piśmie Świętym (por. 1 Kor 6,9-10; Rz 1,29-32; Mk 7,20-23; 1 Kor 5,9-13; 2 Kor 12,21; Ga 5,19-21).

Jan Paweł II w adhortacji Familiaris consortio dopuszczał, że mężczyzna i kobieta żyjący wspólnie w związku nieregularnym „dla ważnych powodów 
- jak na przykład wychowanie dzieci - nie mogą uczynić zadość obowiązkowi rozstania się" (FC, nr 84), a jednak nie tolerował współżycia seksualnego pomiędzy takimi osobami ze względu na jego cudzołożny charakter. Franciszek natomiast, jak można się domyślać na podstawie tekstu jego adhortacji i zaaprobowanej przez niego interpretacji biskupów argentyńskich, skłonny jest takie współżycie tolerować. Pozwala mu na to nie tylko legalistyczne rozumienie okoliczności łagodzących, jakie zdaje się przenikać tekst jego dokumentu, ale także założona w nim płynna koncepcja małżeństwa, dopuszczająca jego formy bliższe i dalsze ewangelicznemu wzorcowi małżeństwa, postrzeganemu przez Franciszka nie jako norma, lecz ideał. Dlatego w przypisie 329 swojej adhortacji Franciszek przedstawia wprawdzie współżycie pomiędzy osobami w związku nieregularnym w sposób czysto deskryptywny, wolny od jakiegokolwiek wartościowania, lecz zarazem do tego współżycia, zawsze określanego jako cudzołóstwo przez Kościół wierny nauczaniu Chrystusa, papież odnosi zacytowany fragment Konstytucji Gaudium et spes Soboru Watykańskiego II, nr 51, dotyczący współżycia małżeńskiego, którego brak może szkodzić trwałości związku. Można więc odnieść wrażenie, że w ten sposób w adhortacji Amoris laetitia dokonuje się niejako legitymizacja współżycia cudzołożnego, gdyż tekst wydaje się wskazywać na pozytywną i niezbędną rolą współżycia pozamałżeńskiego w stabilizowaniu nieprawego związku i utworzonej na jego gruncie naturalnej rodziny.

\section{Nieadekwatność ogólnych norm w odniesieniu do szczególnych sytuacji}

W adhortacji Amoris laetitia przytaczane są wypowiedzi św. Tomasza z Akwinu (AL, nr 304 z odniesieniem do Tomasz z Akwinu, Summa Theologiae I-II, q. 94, a. 4 corp.) oraz Międzynarodowej Komisji Teologicznej (AL, nr 305 z odniesieniem do Międzynarodowa Komisja Teologiczna, $W$ poszukiwaniu etyki uniwersalnej: nowe spojrzenie na prawo naturalne [2009], nr 59). Cytaty te są jednak wyrwane z kontekstu, co sprawia wrażenie ich instrumentalnego wykorzystania. Obydwie te wypowiedzi dotyczą znanego w teorii moralności zagadnienia specyfikacji norm ogólnych i osądu praktycznego w poszczególnych sytuacjach. Podkreślają one, że szczegółowe normy moralne i wnioski rozumowania praktycznego nie wynikają $\mathrm{w}$ sposób czysto dedukcyjny i konieczny z ogólnych norm, a takimi są przykazania prawa naturalnego. Dlatego ogólne zasady nie narzucają się osobie działającej w sposób aprioryczny, oderwany od rozpoznania możliwej do realizacji struktury dóbr i możliwej do uniknięcia struktury zła w konkretnej sytuacji. Natomiast $\mathrm{w}$ tekście adhortacji te dwa teksty użyte są jako rodzaj przestrogi, 
aby w duszpasterskim rozeznaniu związków w sytuacjach nieregularnych nie oceniać w sposób jednoznaczny i aprioryczny osób tworzących taki związek, ponieważ ogólne normy dające podstawy do takiej oceny mogą nie obejmować wielu szczególnych cech tego typu związków i sytuacji. W ten sposób, nie usuwając otwarcie nauki o czynach wewnętrznie złych i absolutnych zakazach moralnych, dokument papieski zdaje się prezentować przekonanie, jakoby zakazy te były zbyt ogólne i nie mogły adekwatnie obejmować wielu przypadków ze względu na unikalny charakter tych ostatnich. Według takiego podejścia na przykład norma absolutna „nie cudzołóż” byłaby zbyt ogólna i mogłaby nie obejmować pozamałżeńskiego współżycia seksualnego w wielu związkach pozostających w unikalnych sytuacjach nieregularnych. Taki zabieg $\mathrm{w}$ efekcie pozbawia tę normę i inne podobne zakazy ich absolutnej mocy wiążącej i wbrew ich naturze dopuszcza wyjątki, których zakazy te miałby rzekomo nie obejmować.

Tymczasem fakt, że w różnych konkretnych przypadkach możliwe jest wyprowadzenie odmiennych sposobów postępowania z ogólnych zasad w zależności od dostępnej struktury dóbr możliwych do realizacji i zła możliwego do unikania, nie przeczy temu, że istnieją specyficzne wzorce ludzkich zachowań, które nigdy nie prowadzą do ludzkiego spełnienia i szczęścia i dlatego są złe zawsze i wszędzie, niezależnie od intencji osoby działającej i okoliczności. Takich czynów nigdy nie wolno popełniać, a co do ich moralnego zła istnieje pewność. Prawda o takich czynach i zabraniających ich popełniania absolutnych zakazach moralnych jest uniwersalna dla wszystkich ludzi, choć oczywiście ich odpowiedzialność moralna za popełnienie takich aktów może być różna w zależności od ograniczeń ich świadomości i dobrowolności działania. O takich czynach, zwanych także wewnętrznie lub przedmiotowo złymi, uczy Pismo Święte i Kościół (por. Mt 25,14-30; AL, nr 303), a ponadto sam św. Tomasz (por. Tomasz z Akwinu 1969, lib. 2 1. 7 n. 11; 1996, IX, q. 7, a. 2; 1982, q. 15, a. 1, arg. 5 - ad 5; 1981-1897, II-II, q. 64, a. 5, ad 3, q. 110, a. 3 corp., ad 4, q. 154, a. 8; III, q. 68, a. 11, arg. 3 - ad 3; 1954, II, 1168), co w tekście adhortacji zupełnie pominięto milczeniem, cytując wybiórczo jedynie tę wypowiedź św. Tomasza, która jest wygodna dla zawartej w dokumencie strategii argumentacyjnej. Taki zabieg sprawia wrażenie nierzetelnej obrony z góry ustalonej tezy za pomocą instrumentalnego wykorzystania wyrwanego z kontekstu cytatu. Ciekawe, że w przypadku czynu wewnętrznie złego, jakim jest cudzołóstwo, św. Tomasz wyraźnie odrzuca możliwość zastosowania epikei, czyli zasady rozumowania, zgodnie z którą w pewnych szczególnych okolicznościach moralny zakaz cudzołóstwa okazałby się nieadekwatny i dlatego nie obejmowałby tych sytuacji, ponieważ w takich przypadkach lepiej służyłoby dobru dokonanie cudzołóstwa, dlatego wówczas nie byłoby ono grzechem (por. Tomasz z Akwinu 1982, q. 15, a. 1, arg. 5 - ad 5). Co więcej, Doktor 
Anielski odrzuca także możliwość bycia zwolnionym, zgodnie z taką logiką, z któregokolwiek przykazania dekalogu, nawet w nietypowych sytuacjach. Zwolnienie $\mathrm{z}$ jakiegoś przepisu prawa mogłoby być uzasadnione wyłącznie wtedy, kiedy postępowanie według litery prawa byłoby sprzeczne z intencją prawodawcy. Jednak, zdaniem św. Tomasza, nie dotyczy to przykazań Dekalogu, ponieważ zawierają one samą intencję prawodawcy, którym jest Bóg (por. Tomasz z Akwinu 1891-1897, I-II, q. 100, a. 8 corp.) ${ }^{7}$. A przecież jednym z tych przykazań, od których nie da się uzyskać zwolnienia, jest przykazanie szóste, stanowiące wyraźny zakaz: „nie cudzołóż”. Ponadto nawet gdyby ktoś dzięki rozumowaniu przyrodzonemu, z natury podatnemu na niedoskonałości, wychodząc z ogólnych zasad prawa naturalnego, jakoś doszedł do wniosku, że w określonej sytuacji cudzołóstwo jest dozwolone lub że pozamałżeńskie współżycie seksualne osoby związanej węzłem małżeńskim nie jest cudzołóstwem, to przecież do takiego wniosku nie powinna dojść żadna osoba, która traktuje poważnie autorytet objawienia Bożego oraz nauczanie samego Chrystusa jako pewne, nadprzyrodzone źródło poznania prawdy. Skoro zatem sam Chrystus uczy, że trwanie w związku opartym na współżyciu seksualnym z osobą związaną węzłem małżeńskim jest cudzołóstwem, to dlaczego namiestnik Chrystusa na ziemi miałby uczyć inaczej niż jego Pan?

Autor adhortacji Amoris laetitia twierdzi, że normy ogólne „w swoich sformułowaniach nie mogą obejmować absolutnie wszystkich szczególnych sytuacji” (AL, nr 304). Wydaje się jednak, że twierdzenie to pełni w adhortacji kontrowersyjną funkcję. Rzeczywiście, normy ogólne na jakimś etapie ich sformułowania mogą nie obejmować adekwatnie pewnych konkretnych nowych przypadków, których istotne moralnie cechy nie zostały jeszcze rozpoznane, co widoczne jest zwłaszcza wtedy, kiedy rozwój cywilizacji przynosi nowe możliwości ludzkiego działania, domagające się oceny moralnej lub regulacji prawnej. Jednak refleksja moralna czy legislacyjna pozwala z czasem na dokładniejsze poznanie tych przypadków oraz na dokonanie odpowiedniej specyfikacji norm ogólnych i sformułowania norm szczegółowych, odnoszących się trafnie do tego typu konkretnych działań. Natomiast byłoby absolutnie fałszywe takie rozumienie cytowanego twierdzenia, które z zasady odmawiałoby normom moralnym możliwości realizacji ich regulacyjnego celu w szczegółowych przypadkach, czyli w sposób absolutny i trwały wyjmowałoby pewne szczegółowe sytuacje spod regulacyjnego oddziaływania jakichkolwiek norm moralnych, nawet już poddanych odpowiedniej specyfikacji. Oznaczałoby to bowiem, że pewnych czynów nigdy nie da się wartościować moralnie, bo ich unikalne cechy uniemożliwiają rozpoznanie ich natury i ich

${ }^{7}$ Więcej na temat zagadnienia czynów wewnętrznie złych i absolutnych zakazów moralnych w ujęciu św. Tomasza z Akwinu zob. Galewicz 2013, s. 283-299. 
moralnego rodzaju, a taki wniosek byłby sprzeczny z charakterystyką obiektywnego porządku moralnego.

Mimo to tekst adhortacji wyraża przekonanie, że każdy przypadek związku w sytuacji nieregularnej jest inny i nie da się wszystkich potraktować według żadnego ogólnego wzorca. „Dlatego «trzeba unikać osądów, które nie uwzględniają złożoności różnych sytuacji i koniecznie zwracać uwagę na sposób, w jaki ludzie żyją i cierpią z powodu stanu, w jakim się znajdują»”" (AL, nr 296 z odniesieniem do Synod Biskupów 2015, nr 51). Z tekstu adhortacji zdaje się zatem wynikać przeświadczenie, że pewność moralna jest obecna w szczegółowych przypadkach, które do tego stopnia mogą różnić się od siebie, że nie da się ich opisać i usystematyzować za pomocą wspólnych im istotnych moralnie cech, czyli nie da się zidentyfikować wspólnej dla nich reguły moralnej istotności. Gdyby jednak takie podejście było prawdziwe, to nie tylko nie byłaby możliwa jakakolwiek refleksja moralna, porządkująca sferę ludzkich działań według moralnie istotnych cech, ale w ogóle nie byłaby możliwa moralność, bo nie byłoby poznawalnych, ogólnych kryteriów oceny moralnej wspólnych dla wszystkich czynów ludzkich. Tymczasem natura obiektywnego porządku moralnego zakłada, że jest on jeden, wspólny dla wszystkich ludzi i ich czynów, pomimo różnych przeszkód, które mogą utrudniać jego poznanie. Skoro więc istnieje jeden, obiektywny i wspólny dla wszystkich ludzi porządek moralny, to istnieją też wspólne kryteria oceny moralnej i nie ma takich czynów, które z zasady znajdują się poza zasięgiem tego porządku i właściwych mu kryteriów oceny. Wprawdzie każdy czyn może mieć określone cechy przypadłościowe, jednostkujące go i odróżniające od pozostałych czynów o tej samej istocie moralnej, to przecież ocena moralna i przyporządkowanie czynu do określonego rodzaju aktów zależy od jego istoty. To zaś zakłada poznawalność moralnie istotnych cech czynu, umiejętność odróżniania ich od jego cech moralnie nieistotnych, oraz powoduje także możliwość generalizacji jego moralnej oceny i sformułowania normy moralnej wspólnej dla czynów o tej samej istocie moralnej.

$\mathrm{Z}$ adhortacji Amoris laetitia można jednak wyprowadzić wniosek, jakoby sytuacje nieregularne powodowały powstanie związków opartych na aktach współżycia seksualnego do tego stopnia unikalnych, że nie da się ich opisać w ten sam sposób za pomocą jakichkolwiek wspólnych, ogólnych kryteriów moralnych i nie da się ich odnieść do wspólnych dla nich norm moralnych. Dlatego, jak następnie można się domyślać na podstawie tekstu papieskiego dokumentu, z uwagi na unikalność tych związków i cementujących je aktów seksualnych, teoretyk moralności, którego zajmuje „rozwijanie zimnej moralności przy biurku", nie jest w stanie ich poznać i opisać moralnie. Ich ostatecznego pewnego wartościowania (o niejasnym odniesieniu do moralności) może dokonać jedynie duszpasterz, dzięki kierującemu się miłością dogłębnemu rozeznaniu duszpasterskiemu, sięgającemu w samo sedno ich unikalności (por. AL, nr 312). 
Ze względu na tę unikalność nawet sam papież uważa za niemożliwe, aby w adhortacji podać jakieś ogólne kryteria takiego rozeznania, bo wspólne kryteria świadczyłyby o wspólnej, istotnej moralnie charakterystyce takich przypadków, a tego właśnie chce papież uniknąć. Jednocześnie adhortacja tę absolutną unikalność pewnych przypadków i brak u nich powszechnych cech moralnych wspólnych dla wielu podobnych przypadków zakłada bez uzasadniania.

W odniesieniu do współczesnych przypadków związków w sytuacjach nieregularnych papież nie podaje $\mathrm{w}$ adhortacji jakichkolwiek ich moralnie istotnych cech, które świadczyłyby o nieadekwatności zastosowania do tych przypadków dotychczas nauczanych przez Kościół norm, a zwłaszcza absolutnego zakazu cudzołóstwa. Jeśli więc cudzołóstwo można zdefiniować jako świadome i dobrowolne współżycie seksualne z osobą, która nie jest współmałżonkiem podmiotu działającego, i jeśli istnieje absolutny moralny zakaz cudzołóstwa, to współżycie seksualne osób tworzących związek pozamałżeński jest cudzołóstwem i jest absolutnie zakazane, bez względu na dodatkowe szczegóły i unikalne cechy takiej sytuacji. Jeśli natomiast intencją autora adhortacji byłoby twierdzenie, że pewne szczegóły sytuacji mogą takie współżycie wyjąć spod tej definicji cudzołóstwa i spod zakazującej je normy, to na poparcie tej tezy wypadałoby podać przynajmniej jakiś przykład takich szczegółów. Bez podania przykładu prezentowane twierdzenie ma rangę przekonania nieuzasadnionego, bez potwierdzenia w faktach. Byłoby więc ono kolejnym elementem pewnej kontrowersyjnej retoryki, a może nawet zamierzonej strategii, sprzyjającej neutralizacji czy relatywizacji nauki o czynach wewnętrznie złych, zabronionych absolutnymi zakazami moralnymi.

\section{Legalistycznie zdeformowana koncepcja miłosierdzia}

Kolejnym tradycyjnym zagadnieniem chętnie przywoływanym przez papieża Franciszka przy różnych okazjach, lecz najwyraźniej rozumianym w adhortacji Amoris laetitia w sposób nietradycyjny, rywalizujący z nauką o czynach wewnętrznie złych i absolutnych zakazach moralnych, jest miłosierdzie (por. AL, nr. 6, 293, 297, 307-312). Miłosierdzie nie jest $\mathrm{w}$ adhortacji nigdzie zdefiniowane i papież zakłada jego intuicyjne rozumienie. To pozwala mu nakłaniać do rozeznania i do miłosierdzia względem tych, którzy tworzą związki na warunkach „które nie odpowiadają w pełni temu, co Pan nam proponuje” (por. AL, $\mathrm{nr} 6)^{8}$. Jednym ze skutków takiego rozeznania i miłosiernego po-

\footnotetext{
${ }^{8}$ Polskie thumaczenie oddaje czasownik proponit jako 'proponuje', ale czasownik ten ma też inne znaczenia, takie jak: 'przedkładać', 'przedstawiać', 'wykładać', 'podawać'. Zatem na tej podstawie nie można krytykować papieża, jakoby z nauki Jezusa uczynił jedynie propozycję.
} 
dejścia może być wówczas tolerowanie takich związków i praktykowanego w nich współżycia seksualnego oraz dopuszczenie tworzących je osób do sakramentów. Taka tolerancja jest możliwa, ponieważ nierozerwalność małżeństwa jest traktowana $\mathrm{w}$ adhortacji jako ideał, a nie absolutna norma wypływająca z prawdy o małżeństwie. Dlatego papież określa rolę i oddziaływanie miłosierdzia nie w odniesieniu do osób, które postępują wbrew prawdzie i naruszają absolutną normę nierozerwalności małżeństwa, lecz jedynie w odniesieniu do osób, które nie spełniają ewangelicznego ideału małżeństwa. W ten sposób dzięki miłosiernemu traktowaniu osoby pozostające w związku nieidealnym zyskują w adhortacji praktyczną dopuszczalność ich wzajemnego współżycia seksualnego, które w takich sytuacjach tradycyjnie Kościół wierny nauce Chrystusa zawsze postrzegał jako cudzołóstwo, czyli czyn wewnętrznie zły i zabroniony absolutnym zakazem moralnym. W wyniku takiego podejścia prezentowana w adhortacji Amoris laetitia koncepcja miłosierdzia harmonijnie wpisuje się w legalistyczną logikę neutralizacji nauki o czynach wewnętrznie złych zabronionych absolutnymi zakazami moralnymi. Możliwość dostrzeżenia wielu elementów tej logiki w tekście adhortacji oraz ich harmonijne dopasowanie w jedną całość pozwalają przypuszczać, że nie jest to przypadkowa koincydencja niepowiązanych ze sobą czynników, lecz raczej zamierzona strategia, za którą przynajmniej urzędowo odpowiada sam autor adhortacji.

Zagadnienie miłosierdzia $\mathrm{w}$ adhortacji łączy się dodatkowo także $\mathrm{z}$ koncepcją okoliczności łagodzących. Okoliczności łagodzące mogą być niewątpliwie czynnikiem pobudzającym do postawy miłosierdzia wobec grzeszników, a samo uznanie ich wpływu redukującego odpowiedzialność moralną i winę może być przejawem miłosierdzia. Jednak w perspektywie legalistycznego podejścia do moralności także postawa miłosierdzia zaczyna być pojmowana legalistycznie. Skoro legalizm wypacza naturę moralności, to wypacza też naturę miłosierdzia, sprowadzając je z poziomu cnoty usprawniającej do realizacji dobra, do poziomu emocjonalnej litości, wyzwalającej od uciążliwości związanych z przestrzeganiem prawa moralnego. Miłosierdzie, którego natura zostaje wypaczona przez legalizm laksystyczny, przejawia się w takim minimalizowaniu za pomocą okoliczności łagodzących poczucia odpowiedzialności moralnej i winy, które w rezultacie doprowadza do tolerowania postępowania sprzecznego z normą. W taki jednak sposób wcale nie pomaga się ludziom, którym dobre życie się nie udaje, aby stopniowo dorastali moralnie do prowadzenia życia coraz lepszego, dającego człowiekowi spełnienie i szczęście.

Tymczasem autentyczne miłosierdzie skierowane jest nie na minimalizowanie odpowiedzialności moralnej i winy, aby tolerować naruszanie normy, ale przede wszystkim na minimalizowanie braków, bo to braki są źródłem niespełnienia i nieszczęścia, a nie odpowiedzialność moralna za dokonane zło 
i związana z tym wina. Prawdziwa cnota miłosierdzia dysponuje więc nie do tego, aby poprzestawać na uwolnieniu grzesznika od winy za dokonane zło, ale do tego, aby eliminować dokonywanie i doświadczanie zła. Nawiązując do terminologii medycznej, można powiedzieć, że autentyczne miłosierdzie polega na zaradzaniu nieszczęściu człowieka, jednak nie w sposób wyłącznie objawowy, ale przede wszystkim przyczynowo, ponieważ miłosierdzie jest cnotą, czyli sprawnością duszy dysponującą człowieka do urzeczywistniania prawdziwego dobra. Miłosierdzie natomiast nie jest uczuciem. W tym miłosierdzie różni się od litości, która nie jest cnotą, lecz uczuciem, i na poziomie emocjonalnym jest podobna do miłosierdzia, dlatego może być z nim mylona. Na przykład eutanazja polega na zabiciu z litości, a nie z miłosierdzia, osoby nieuleczalnie cierpiącej. W taki bowiem sposób ten, kto dopuszcza się eutanazji, z litości zaradza cierpieniu człowieka kosztem jednego z najbardziej podstawowych jego dóbr, jakim jest samo życie (por. Plich 2008, s. 312-314). Miłosierdzie natomiast, które jest cnotą i dlatego ze swej natury liczy się z obiektywnym porządkiem dobra, nie pozwala na takie czysto objawowe rozwiązanie ze szkodą dla prawdziwego dobra.

Niestety legalistyczne podejście do moralności, którego przejawy w tekście adhortacji pozwala ujawnić jej uważna lektura, myli miłosierdzie z litością. Pragnąc bowiem zmniejszenia cierpienia, autor adhortacji skłonny jest tolerować i dopuszczać do sakramentów związki nieregularne, oparte na pożyciu cudzołożnym, które objawowo są podobne do małżeństwa, jednak przyczynowo i istotowo nim nie są. Wygląda na to, że papież Franciszek woli dopuścić niespójność i chaos, jakoby dawały one wolną przestrzeń dla miłosierdzia i działania Ducha Świętego, natomiast ze sceptycyzmem odnosi się do spójnego i konsekwentnego porządku, jakoby miał on generować ciasny rygoryzm oraz uniemożliwiać miłosierdzie i działanie Ducha Świętego (por. AL, nr 308). Niewątpliwie autentyczne miłosierdzie, które jest cnotą, w wyniku właściwie rozeznanych okoliczności łagodzących może w określonych przypadkach skłonić do łagodniejszego osądzenia winy i do zredukowania lub nawet do odwołania kary, ale nigdy nie polega na odwołaniu prawdy i wynikającego z niej porządku normatywnego. Kościół ma przygotowaną odpowiedź miłosierdzia wobec osób żyjących w związku pozamałżeńskim i tworzących rodzinę naturalną. Nie zamyka takim osobom możliwości przystępowania do sakramentów, ale pod warunkiem poszanowania prawdy i wynikającej z niej normy, dotyczącej takiego związku i obecnych w nim aktów współżycia seksualnego.

Papież Franciszek - jak wolno przypuszczać - byłby raczej niezadowolony z tej odpowiedzi, gdyż prawdopodobnie uważałby ją za zbyt restrykcyjną i prowadzącą do wykluczenia zbyt wielu ludzi z dostępu do sakramentów. Wprawdzie papież słusznie dostrzega, że miłosierdzie nie jest absolutnie bez- 
warunkowe (bo wszystko, co istnieje, ma przecież jakąś istotę i tym samym istotne warunki bycia tym, czym jest), że ,nie wyklucza [ono] sprawiedliwości i prawdy" oraz, „że miłosierdzie jest pełnią sprawiedliwości i najjaśniejszą manifestacją prawdy Bożej” (AL, nr 311). Jednak zwłaszcza to ostatnie stwierdzenie wydaje się przedstawione w adhortacji w taki sposób, jakby miłosierdzie było postawą, która sama ze swej natury generuje swoje własne warunki, jakim są sprawiedliwość i prawda. Tymczasem wcale tak nie jest. Miłosierdzie może być rozwijane wyłącznie wtedy, kiedy uprzednio spełnione są te istotne warunki, gdyż bez ich spełnienia pozostaje wyłącznie uczucie litości, które na poziomie przeżyć emocjonalnych przypomina miłosierdzie. Moralność, która polega na kierowaniu się uczuciem litości i z litości czyni wartość i kryterium moralnej dobroci, w gruncie rzeczy ma charakter emotywistyczny i jest obca nauczaniu moralnemu Kościoła. Prawda i sprawiedliwość są bardziej pierwotne od miłosierdzia, bo one w wielu swoich przejawach mogą istnieć bez miłosierdzia, podczas gdy miłosierdzie w ogóle bez nich nie może istnieć (por. Plich 2008, s. 354-355). Dlatego duszpasterz kierujący się autentycznym miłosierdziem zawsze będzie się liczył z prawdą o nierozerwalności małżeństwa i nie będzie w imię miłosierdzia tolerował związków, które żyją sprzecznie $\mathrm{z}$ tą prawdą.

Z wyjątkiem rozdziału ósmego pozostała część adhortacji zawiera bardzo ciekawe i wartościowe rozważania, gdzie wiele osób znajdzie ważne dla siebie wskazania praktycznej mądrości. Z pewnością zainspirują one także duszpasterzy oraz spowiedników, tak jak zainspirowały autora niniejszego artykułu. W rozdziale ósmym wyraźnie widać dobre intencje i autentyczną troskę autora adhortacji, który nie może przejść obojętnie wobec osób rozwiedzionych, żyjących $\mathrm{w}$ powtórnych związkach, pozbawionych duszpasterskiej opieki, zwłaszcza że wiele z nich znalazło się w tym stanie pod wpływem wyrządzonej im krzywdy lub pod wpływem innych trudnych okoliczności życiowych. Na pewno jednak rozwiązania zaprezentowane w ósmym rozdziale adhortacji, zdające się zmierzać do osłabienia nauki o czynach wewnętrznie złych i absolutnych zakazach moralnych, nie są właściwym środkiem zaradczym na problemy małżeńskie. Otwierają one drogę do praktycznie nieograniczonego subiektywistycznego usprawiedliwiania innych poważnych niegodziwości, które Kościół zawsze postrzegał jako czyny wewnętrznie i poważnie nieuporządkowane i tym samym bezwzględnie zakazane moralnie. Ostatecznie więc wypromowana $\mathrm{w}$ adhortacji w dobrej wierze retoryka i strategia może doprowadzić do rozmycia moralnej wrażliwości chrześcijan, a w konsekwencji do poważnego spustoszenia ich duchowego życia. 
Być może jednak istnieje perspektywa przyszłego rozwoju nauczania o nierozerwalności małżeństwa, umożliwiająca wypracowanie dodatkowych kryteriów kanonicznych jego ważności. Możliwym kierunkiem takich poszukiwań, zwłaszcza w kontekście ekumenicznym, wydaje się np. dalsze pogłębienie i doprecyzowanie znaczenia greckiego terminu porneia, użytego w Mateuszowym przekazie nauczania samego Jezusa ${ }^{9}$. Termin ten stanowi zastrzeżenie, za pomocą którego Jezus ogranicza zakres rozumienia cudzołóstwa, będącego skutkiem naruszenia normy nierozerwalności małżeństwa, a niewykluczone, że w ten sposób ogranicza także zakres treści tej właśnie normy. O ile nie może być owocem autentycznego rozwoju doktryny jakiekolwiek przyzwolenie na życie i czyny sprzeczne z normą i dlatego wewnętrznie złe, o tyle owoc takiego rozwoju może stanowić pogłębienie rozumienia samej normy, powodujące zawężenie zakresu jej treści. W ten sposób przypadki, które wcześniej wydawały się sprzeczne z szerokim i nieprecyzyjnym ujęciem normy nierozerwalności małżeństwa, a przez to postrzegane były jako czyny wewnętrznie złe, mogą okazać się niesprzeczne z normą i moralnie dopuszczalne w wyniku bardziej adekwatnego i precyzyjnego zawężenia zakresu jej treści. Choć rozwiązania wypromowane w adhortacji Amoris laetitia wydają się wysoce kontrowersyjne, to być może są one przynajmniej znakiem zdrowej intencji, która została ukształtowana pod wpływem Bożego światła, lecz powinna być urzeczywistniana w sposób bezpieczny dla spójności całej doktryny. Z perspektywy czasu, który upłynął od ukazania się adhortacji, trudno nie zauważyć, że wywołała ona w Kościele chaos i zamieszenie, a te nie są owocami Ducha Świętego. Skoro jednak Jezus zapewnia nas o swojej obecności, o prowadzeniu Kościoła przez Ducha Świętego do pełnej prawdy i o tym, że bramy piekielne nie przemogą Kościoła zbudowanego na apostole Piotrze i jego następcach, to wypada mieć nadzieję, że Kościół wyjdzie z tego eksperymentu i zamieszania umocniony i że także krytyczne reakcje, z jakimi spotkała się adhortacja, przyczynią się do tego.

\section{LEGALISTIC NEUTRALIZATION OF THE TEACHING ON INTRINSI- CALLY EVIL ACTS AND ABSOLUTE MORAL PROHIBITIONS IN THE EXHORTATION AMORIS LAETITIA}

\section{SUMMARY}

The Catholic Church's traditional teaching on intrinsically evil acts and absolute moral prohibitions is clearly problematic for the pastoral and disciplinary solutions proposed in the eighth chapter of Pope Francis's Apostolic Exhortation Amoris laeti-

\footnotetext{
${ }^{9}$ Termin ten jest zwykle thumaczony jako 'nierząd' lub 'rozpusta' - por. Mt 19,9.
} 
tia. Yet this teaching is a part of the moral doctrine of the Church, and it is impossible to contradict this teaching without coming into conflict with that doctrine. This article thus discusses major elements of the strategy of argument that seems to be applied in the Exhortation, in order to neutralize and relativize the traditional doctrine without causing evident contradictions within it. One of these strategic efforts consists of making use of the traditional concept of mitigating circumstances that lessen the negative moral evaluation of a human act. However, this traditional concept seems to be used in the Exhortation to promote a legalistic approach to morality. A so-called 'laxist' variant of legalism makes use of a certain interpretation of moral norms in order to defend people against the charge of their infringement. This approach does not take into account the influence that human acts have on the realization of the true human good, which is the goal of morality and the reason that norms exist. Legalism, therefore, does not help people to achieve their true end, which is fulfilment and happiness, but leads them into harmful moral minimalism. Another way to neutralize the teaching on intrinsically evil acts and absolute moral prohibitions consists in a legalistic reinterpretation of the law of gradualness, which is the concept taught by John Paul II. In order to carry out this reinterpretation, the binding norm of the indissolubility of marriage is substituted in the Exhortation Amoris laetitia with the ideal of indissolubility, which by its very nature is supererogatory (i.e., something 'above the call of duty'). Yet another strategic method of neutralizing the traditional teaching on intrinsically evil acts and exceptionless moral prohibitions is a certain skepticism concerning the very possibility of the application of general norms to certain particular cases. The text makes an impression that these cases may be unique to such an extent that general norms cannot apply absolutely to them. Yet this skepticism consequently denies to the human mind the ability to uncover moral essence of some human acts, or even situates these acts wholly outside the domain of morality. In support of this skepticism, the Exhortation employs a statement of Saint Thomas Aquinas that has been taken out of context, skipping over the places where Saint Thomas explicitly teaches that there are absolutely morally forbidden acts that are deemed so because of their objective intrinsic disorderedness. Finally, the article looks at the concept of mercy, which is attenuated in the Exhortation probably in order to make possible this legalistic neutralization of the teaching on intrinsically evil acts and absolute moral prohibitions. In the Exhortation, mercy seems to be deprived of its status as a virtue and appears instead to be reduced to something akin to pity, which is a purely emotional reaction that has no relationship to the broader horizon of objective human good. Apparently following this strategy of argument, Pope Francis seems to demonstrate that the pastoral and disciplinary solutions he presents are coherent with traditional doctrine. Yet, while invoking certain elements of moral doctrine, he invents for these elements new meanings that explicitly differ from those they had until now.

Słowa kluczowe: Amoris laetitia; czyny wewnętrznie złe; absolutne zakazy moralne; cudzołóstwo; legalizm; okoliczności łagodzące; prawo stopniowości; nierozerwalność małżeństwa; normy a ideały; specyfikacja norm ogólnych; miłosierdzie 
Keywords: Amoris laetitia; intrinsically evil acts; absolute moral prohibitions; adultery; legalism; mitigating circumstances; the law of gradualness; indissolubility of marriage; norms vs. ideals; specification of general norms; mercy

\section{BIBLIOGRAFIA}

Pismo Święte Starego i Nowego Testamentu (2014), Poznań.

\section{Nauczanie Kościoła}

Benedykt XII (1336), Konstytucja Benedictus Deus (29-I-1336 r.) w: H. Denzinger, Enchiridion symbolorum, definitionum et declarationum de rebus fidei et morum. Compendium of Creeds, Definitions, and Declarations of the Catholic Church, red. P. Hunermann, R. Fastiggi, A. Englund Nash, San Francisco $2012^{43}$, nr 1002.

Franciszek (2013), Adhortacja apostolska Evangelii gaudium, „Acta Apostolicae Sedis” 105, s. $1019-1137$.

Franciszek (1016), Adhortacja apostolska Amoris laetitia, „Acta Apostolicae Sedis” 08, s. 311-446.

Franciszek (2015), Littera apostolica Iubilaeo Extraordinario Misericordiae Adveniente, ad Venerabilem Fratrem Salvatorem Fisichella, Praesidem Pontificii Consilii de Nova Evangelizatione Promovenda, „Acta Apostolicae Sedis” 107, s. 974-976. Wersja polska: List, na mocy którego udziela się odpustu z okazji Jubileuszu Miłosierdzia, https://w2.vatican.va/content/francesco/pl/ letters/2015/documents/papa-francesco_20150901_lettera-indulgenza-giubileo-misericordia. html [dostęp: 05.05.2018].

Franciszek (2016), List apostolski Misericordia et misera, „Acta Apostolicae Sedis” 108, s. 1311$-1327$.

Franciszek (2016), Epistula apostolica ad Excellentissimum Dominum Sergium Alfredum Fenoy, delegatum Regionis Pastoralis Bonaërensis, necnon adiunctum documentum (de praecipuis rationibus usui capitis VIII Adhortationis post-synodalis “Amoris Laetitia”), „Acta Apostolicae Sedis" 108, s. 1071-1074.

Jan Paweł II (1982), Adhortacja apostolska Familiaris consortio, „Acta Apostolicae Sedis” 74, s. 81-191.

Jan Paweł II (1985), Adhortacja apostolska Reconciliatio et paenitentia, „Acta Apostolicae Sedis” 77, s. 185-275.

Jan Paweł II (1993), Encyklika Veritatis splendor, „Acta Apostolicae Sedis” 85, s. 1134-1228.

Jan Paweł II (1996), Lettera al Card. William W. Baum in occasione del corso sul foro interno organizzato dalla Penitenzieria Apostolica (22-III-1996 r.), w: Insegnamenti, XIX, 1 (1996), 589, https://w2.vatican.va/content/john-paul-ii/it/letters/1996/documents/hf_jp-ii_let_19960322_ penitenzieria.html [dostęp: 05.05.2018].

Paweł VI (1968), Encyklika Humanae vitae, „Acta Apostolicae Sedis” 60, s. 481-503.

Katechizm Kościoła katolickiego (2002), Poznań.

Kodeks prawa kanonicznego. Komentarz (2011), edycja polska na podstawie wydania hiszpańskiego, red. P. Majer, Kraków.

Kongregacja Nauki Wiary (1994), List do biskupów Kościoła katolickiego na temat przyjmowania Komunii św. przez wiernych rozwiedzionych żyjacych w nowych zwiąkach, „Acta Apostolicae Sedis" 86, s. 974-979.

Kongregacja Nauki Wiary (1980), Deklaracja Iura et bona, „Acta Apostolicae Sedis” 72, s. 542-552.

Międzynarodowa Komisja Teologiczna (2010), W poszukiwaniu etyki uniwersalnej: nowe spojrzenie na prawo naturalne, tłum. R. Kiełtyka, Kraków. 
Papieska Rada ds. Interpretacji Tekstów Prawnych (2000), Deklaracja dotyczaca dopuszczania do Komunii Świętej wiernych rozwiedzionych i żyjacych w powtórnych związkach (24-VI-2000), „Communicationes” 32, s. 159-162.

Sobór Trydencki (2004), Sesja VI, Dekret o usprawiedliwieniu, Sesja XIII, Dekret o Sakramencie Eucharystii, w: Dokumenty Soborów Powszechnych. Tekst łaciński i polski, red. A. Baron i H. Pietras, t. IV, Kraków, s. 289-325, 445-471.

Sobór Watykański II (2002), Konstytucja Gaudium et spes, w: Sobór Watykański II, Konstytucje, dekrety, deklaracje, Poznań, s. 526-606.

Synod Biskupów (2015). XIV Zwyczajne Zgromadzenie Ogólne, Relacja Końcowa Synodu Biskupów dla Ojca Świętego Franciszka, (24-X-2015), Libreria Editrice Vaticana. http://niedziela.pl/ download/synod_relacja_koncowa.pdf [dostęp: 25.08.2018].

\section{Prace teologiczne i filozoficzne}

Aurelius Augustinus [br.], Contra Mendacium, ed. J.P. Migne, PL 40, Bibliotheca Cleri Universa, Brepols-Turnhout, s. 518-547.

Chaput Ch.J. (2017), The Splendor of Truth in 2017, „First Things” 10,

https://www.firstthings.com/article/2017/10/the-splendor-of-truth-in-2017 [dostęp: 05.052018].

Galewicz W. (2013), Tomasz z Akwinu o bezwzględnych zakazach moralnych, „Przegląd Tomistyczny", t. XIX, s. 283-299.

Lepa F. (2013), Kompetencje, uprawnienia i obowiązi w Kościele katolickim, Białystok.

Nowicka U. (2016), Przeszkoda przyzwoitości publicznej, w: Przeszkody malżeńskie w prawie kanonicznym, red. Wojciech Góralski, Warszawa, s. 437-462.

Piechowiak M. (2005), Legalizm, w: Powszechna encyklopedia filozofii, red. A. Maryniarczyk, t. 6, Lublin, s. 286-289.

Pinckaers S.T. (1994), Źródła moralności chrześcijańskiej. Jej metoda, treść, historia, tłum. A. Kuryś, Poznań.

Plich R. (2008), Koncepcja miłosierdzia wedlug świętego Tomasza z Akwinu. Geneza, interpretacja i rozwinięcie, „Przegląd Tomistyczny” XIV, s. 291-358.

Thomas de Aquino (1891-1897), Summa Theologiae, ed. Commissio Leonina, t. 6-9, Romae.

Thomas de Aquino (1982), Questiones disputatae de malo, ed. Commissio Leonina, t. 23, RomaParis.

Thomas de Aquino (1969), Sententia libri Ethicorum, ed. Commissio Leonina, t. 47, 1, Romae.

Thomas de Aquino (1996), Quaestiones quodlibetales, ed. Commissio Leonina, t. 25, 1, RomaParis.

Thomas de Aquino (1954), In duo praecepta caritatis et in decem legis praecepta, w: Opuscula theologica, t. 2, Taurini-Romae, s. 245-271.

Robert Plich OP - ur. 1966, absolwent Akademii Medycznej w Warszawie, doktor teologii, wicerektor i wykładowca teologii moralnej w Kolegium Filozoficzno-Teologicznym Dominikanów w Krakowie oraz na Uniwersytecie Papieskim Jana Pawła II w Krakowie. 